\title{
Natural selection, selective breeding, and the evolution of resistance of honeybees (Apis mellifera) against Varroa
}

\author{
Jacques J. M. van Alphen ${ }^{1,2^{*}}$ and Bart Jan Fernhout ${ }^{2}$
}

\begin{abstract}
We examine evidence for natural selection resulting in Apis mellifera becoming tolerant or resistant to Varroa mites in different bee populations. We discuss traits implicated in Varroa resistance and how they can be measured. We show that some of the measurements used are ambiguous, as they measure a combination of traits. In addition to behavioural traits, such as removal of infested pupae, grooming to remove mites from bees or larval odours, small colony size, frequent swarming, and smaller brood cell size may also help to reduce reproductive rates of Varroa. Finally, bees may be tolerant of high Varroa infections when they are resistant or tolerant to viruses implicated in colony collapse. We provide evidence that honeybees are an extremely outbreeding species. Mating structure is important for how natural selection operates. Evidence for successful natural selection of resistance traits against Varroa comes from South Africa and from Africanized honeybees in South America. Initially, Varroa was present in high densities and killed about 30\% of the colonies, but soon after its spread, numbers per hive decreased and colonies survived without treatment. This shows that natural selection can result in resistance in large panmictic populations when a large proportion of the population survives the initial Varroa invasion. Natural selection in Europe and North America has not resulted in large-scale resistance. Upon arrival of Varroa, the frequency of traits to counter mites and associated viruses in European honey bees was low. This forced beekeepers to protect bees by chemical treatment, hampering natural selection. In a Swedish experiment on natural selection in an isolated mating population, only $7 \%$ of the colonies survived, resulting in strong inbreeding. Other experiments with untreated, surviving colonies failed because outbreeding counteracted the effects of selection. If loss of genetic variation is prevented, colony level selection in closed mating populations can proceed more easily, as natural selection is not counteracted by the dispersal of resistance genes. In large panmictic populations, selective breeding can be used to increase the level of resistance to a threshold level at which natural selection can be expected to take over.
\end{abstract}

Keywords: Honeybee, Varroa destructor, Resistance, Virus tolerance, Natural selection, Selective breeding, Hygienic behaviour, Grooming, Recapping

\footnotetext{
* Correspondence: jacques.vanalphen@naturalis.nl

${ }^{1}$ Naturalis Biodiversity Centre, 2333 CR Leiden, The Netherlands

${ }^{2}$ Arista Bee Research Foundation, Nachtegaal 2, 5831 WL Boxmeer, The

Netherlands
}

(c) The Author(s). 2020, corrected publication 2020. Open Access This article is licensed under a Creative Commons Attribution 4.0 International License, which permits use, sharing, adaptation, distribution and reproduction in any medium or format, as long as you give appropriate credit to the original author(s) and the source, provide a link to the Creative Commons licence, and indicate if changes were made. The images or other third party material in this article are included in the article's Creative Commons licence, unless indicated otherwise in a credit line to the material. If material is not included in the article's Creative Commons licence and your intended use is not permitted by statutory regulation or exceeds the permitted use, you will need to obtain permission directly from the copyright holder. To view a copy of this licence, visit http://creativecommons.org/ licenses/by/4.0/. The Creative Commons Public Domain Dedication waiver (http://creativecommons.org/publicdomain/zero/1. 0/) applies to the data made available in this article, unless otherwise stated in a credit line to the data. 


\section{Introduction}

Varroa destructor (Anderson and Truman, 2000) is an external parasitic mite of honeybees that shifted from its original host Apis cerana, the Asian hive bee, to Apis mellifera, the European honeybee. In the mid 1800s, settlers from western Russia carried A. mellifera to the far southeastern corner of Russia, into an area where $A$. cerana occurs naturally [1]. Contact between the two species resulted in the introduction of Varroa to $A$. mellifera. The Varroa mite arrived in Moscow during the 1950s with honeybees from the east. The parasite spread rapidly and colonized western Europe and North America in the early 1980s, and since its invasion from Russia, Varroa has been the major mortality factor of honeybees. Varroa mites are vectors of several bee viruses, and at high mite densities these viruses cause colony collapse [2]. While it does not cause colony mortality in its original host A. cerana [3, 4], it became and remains devastating to apiculture and to natural populations of $A$. mellifera in Europe and feral populations in North America. One reason why Varroa is so virulent on $A$. mellifera is that it can breed in worker brood and so achieve a long reproductive season, while in A. cerana, pupae from worker cells with reproducing mites are always removed [5] and breeding is restricted to the short season during which drones are produced.

Varroa has been present in European and American A. mellifera populations for almost 40 years and, as an important mortality factor, it presumably exerts strong natural selection for resistance in these populations. We call a bee colony resistant when it is able to limit the population size of Varroa, to a density that does not cause mortality.

In western Europe and North America, hives are frequently treated with acaricides, natural acids, or essential oils to control Varroa, and Varroa reproduction is disrupted by other apicultural measures [6]. Moreover, a large proportion of the hives are regularly requeened. These practices are thought to hamper natural selection for resistance against Varroa. However, not all beekeepers treat their colonies against Varroa, and in Europe, where A. mellifera is native, wild colonies of honey bees were not uncommon when Varroa arrived [7]. Likewise, populations of feral colonies of honeybees in North America are exposed to natural selection. Evidence for small-scale natural selection from some of these untreated colonies provides insight into why natural selection in the European honeybee has not resulted in population-wide resistance.

\section{Traits contributing to Varroa resistance} Varroa Resistance in A. cerana

The mite stably coexists with its original host. Apis cerana workers prevent the growth of $V$. destructor populations by different behavioural traits known as 'grooming', 'uncapping and removing' and 'entombing' $[4,8]$. Apis cerana bees groom themselves ('auto-grooming') and also perform grooming dances to recruit nestmates to engage in social grooming ('allo-grooming'). This often results in the removal of phoretic adult mites and inflicts significant mortality among them. The uncapping of worker cells with reproducing Varroa and the subsequent removal of the parasitized pupae result in the removal of mite offspring before they have been able to reproduce [5]. This is an important factor in preventing the mite population to grow to harmful densities. Of Varroa females that enter a worker cell, $90 \%$ do not reproduce, which could be caused by a so-called "brood effect", i.e. the suppression of Varroa reproduction by the brood. The few that do lay eggs fail because of the uncapping and removing behaviour. In $A$. cerana, Varroa only reproduces successfully in drone cells. In drone cells that have been colonized by two or more adult females, the host often dies [4]. Apis cerana workers leave the dead drone brood capped, thus entombing the reproducing parasites and their offspring and causing mortality of up to $25 \%$ among the mites [4]. Drones are produced during a relatively short season $[9$, $10]$, allowing the mites to produce only 3-5 generations per year. This is one of the reasons why Varroa is an innocuous parasite of $A$. cerana.

\section{Traits for Varroa resistance in A. mellifera}

Three of the traits that provide resistance against Varroa in A. cerana, are also present in European A. mellifera populations, albeit in low frequency: the uncapping of Varroa-infected cells and subsequent removal of parasitized pupae, as well as auto- and allo-grooming [11]. Another trait that might confer resistance against Varroa is the "brood effect". The mechanism for the suppression of mite reproduction is a change in a chemical signal issued by a developing worker larva that, if unaltered, would be used by Varroa mites as a signal to initiate reproduction $[12,13]$. Entombing has not been observed in A. mellifera. We first review the evidence for the traits that confer or are thought to confer resistance. We show that evidence cited in support of a particular resistance trait could sometimes also be produced by one of the other traits (Fig. 1). Next, we review the evidence that natural selection has resulted in resistance against Varroa in A. mellifera in Africa, Europe, and the Americas, and the roles played by the different resistance traits.

Uncapping of Varroa-infested cells and removal of parasitized pupae.

\section{Hygienic behaviour}

Hygienic behaviour was discovered by Park and coworkers [14]. They observed that bees in colonies that 


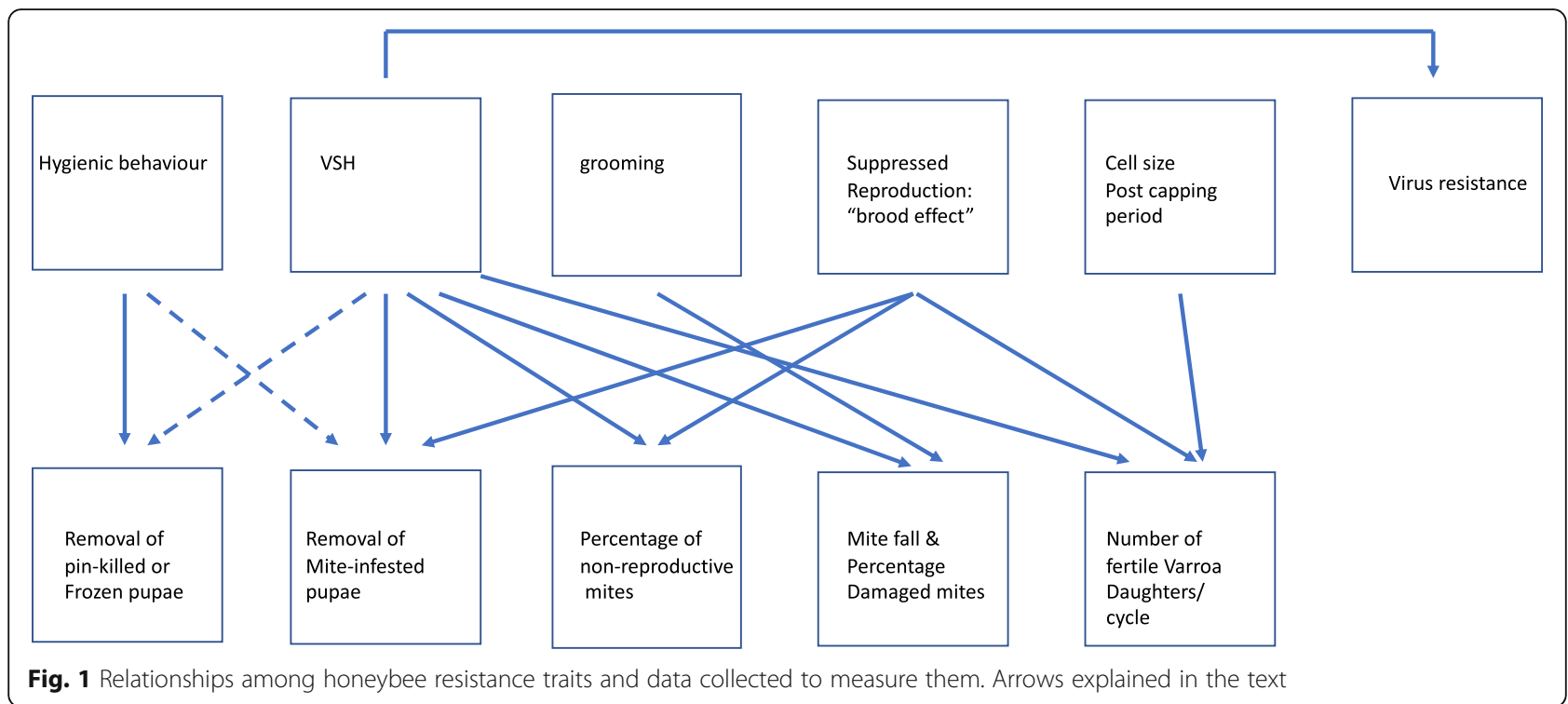

appeared to be resistant against American foulbrood removed larvae from cells inoculated with the disease. Their results indicated that the behaviour was heritable. Woodrow \& Holst [15] labelled this activity "hygienic behaviour" and provided further evidence that resistance to American foulbrood in a honeybee colony consists in its ability to detect and remove diseased brood before the causative organism, B. larvae, reaches the infectious spore stage in the diseased larvae. Rothenbuhler [16] studied the genetics of hygienic behaviour and provided evidence that it is compatible with two recessive genes coding for the behaviour. Later research $[17,18]$ found evidence that more genes are involved, which is not surprising for a behavioural trait. Indeed, Harpur et al. [19] found 73 candidate genes associated with hygienic behaviour. Most of those genes play roles in regulating the expression of genes involved in neuronal development, which could explain why hygienic bees are more receptive to olfactory signals associated with dead brood.

Woodrow \& States [20] already suggested that hygienic behaviour was not specific to American foulbrood: " ... it is likely that the removal of diseased brood is a common behaviour of bees" (cited in [21]. Indeed, subsequent studies $[22,23]$ showed that adult bees from some colonies also removed larvae infected with chalk brood from their cells within $24 \mathrm{~h}$, and that this behaviour also plays an important role in the resistance of bees against this disease $[24,25]$. Based on the belief that the hygienic response to diseased and dead brood is general, a test for hygienic behaviour using freeze-killed brood was designed [23, 26, 27].

The belief that the hygienic behaviour is a general response to diseased and dead brood also led to the hypothesis that hygienic behaviour could play a role in resistance against Varroa. This hypothesis was tested by Boecking \& Drescher [28] and Spivak [29]. Boecking and Drescher [28] found a positive correlation $(r=0.74)$ between the removal of brood infested with two mites per cell and the removal of freeze-killed brood, suggesting that the hygienic response to Varroa-infected cells can at least in part be explained by the general response of hygienic bees to dead and diseased larvae. Spivak [29] repeated and extended these experiments with similar, albeit variable results.

Hence, hygienic bees selected for removing dead larvae show a higher incidence of removing larvae from cells infested with Varroa than non-hygienic control bees (Fig. 1). However, in Boecking \& Drescher's [28] study, this only explained $55 \%$ of the variance. Danka et al. [30] also found only a weak relation between the removal of dead brood and VSH behaviour. Likewise, Boecking et al. [31] showed that the rate of removal of pin-killed larvae correlates with the rate of removal of Varroa infested cells, but that this accounted for only $37 \%$ of the variance. They termed the removal of larvae from Varroa infested cells as "Varroa-specific hygiene", and were first in recognizing that the genetic background of bees removing pupae from Varroa-infested cells is different from bees that only remove killed pupae.

\section{Varroa-sensitive hygiene}

Evidently, apart from general hygienic behaviour, other traits must be involved in the removal of pupae from Varroa infested cells. The cues bees use to detect and remove frozen or pin-killed pupae are not necessarily the same as those used to detect and remove miteinfested pupae. Harbo \& Hoopingarner [32] looked for heritable resistance of honeybees without limiting 
themselves to hygienic behaviour. As natural mating of bee queens results in queens inseminated by multiple males, they used queens artificially inseminated with sperm of only a single male to ensure that resistance characteristics could be strongly expressed by a whole colony. Experimental colonies were infested with equal densities of mites and 63 or 70 days later the mite population size in the colonies was determined. In addition, they measured the incidence of hygienic behaviour using sections of frozen brood, determined the proportion of damaged fallen mites as a measure for grooming behaviour, the incidence of non-reproduction of mites that were found inside capped cells, and duration of the capped period as a measure for developmental time. Of these traits, only the percentage non-reproduction showed a negative correlation with the increase in the mite population that explained $53 \%$ of the variance. They concluded that suppressed mite reproduction (SMR) could be an important resistance trait against Varroa.

In a later study, Harbo and Harris [33] measured the heritability of potential traits for resistance and found that suppression of mite reproduction, hygienic behaviour and proportion of mites in brood cells were candidates for selection due to high heritability. They then started a programme for the selection of bees with the ability to suppress reproduction in the mites, that after about five generations of selection produced colonies that had $<6 \%$ of their mites classified as reproductive in worker cells [34]. Ibrahim \& Spivak [35] hypothesized that the selective removal of brood infested with reproductive mites could explain the observed decrease in percentage reproductive mites. Harbo \& Harris [34] tested this hypothesis. They placed frames with newly capped worker brood in SMR and in control colonies and counted Varroa-infested cells and measured the proportion of reproducing mites after 7-9 days. They found that in SMR colonies the percentage of infested cells had been reduced from 22 to $9 \%$, and the percentage of infested cells containing reproducing mites had decreased from 71 to $20 \%$. The number of cells containing non-reproducing mites was not different between SMR and control colonies. These results show that in the SMR colonies, cells containing reproducing mites had disappeared, and cells containing non-reproducing mites had been left untouched. This is evidence that SMR bees show hygienic behaviour preferentially to cells with reproducing mites. Hence, this particular form of hygienic behaviour is causing an increase in the percentage of non-reproducing mites by reducing the proportion of reproducing mites (Fig. 1).

Harbo \& Harris [36] and Harris, [37], Harris et al. [38] and Kim et al. [39] confirmed these findings. Harris [37] renamed SMR and called the behaviour of uncapping cells containing reproducing Varroa and the removal of pupae from such cells "Varroa Sensitive Hygiene" (VSH), a process that results in the removal of mite offspring before they are able to reproduce successfully, thus interrupting the reproductive cycle of the Varroa. VSH behaviour is a heritable trait that responds well to selection [33]. Bees with VSH recognize cells containing reproducing Varroa [12, 13, 40]. There are indications that at least 2 major genes with additive effects are involved [41]. Tsuruda et al. [42] did a QTL analysis for VSH and found two QTL's, one on chromosome 9 and one on chromosome 1 , together explaining only $10 \%$ of the variance. On average, individuals that were homozygous for the VSH allele were more likely to be individuals who were observed exhibiting VSH. Spöter et al. [43] found six candidate genes and Scannapieco et al. [44] found five genes associated with VSH behaviour. It is likely that some of the genes involved in hygienic behaviour also play a role in VSH.

The proportion of workers in a colony expressing VSH behaviour is positively correlated with the proportion of non-reproducing mites in the brood [34, 36]. This is because VSH bees preferentially attack cells with reproducing mites $[34,38]$.

A low frequency of VSH behaviour must be present in almost every population of European honeybees in Europe and North America, because it has been found when looked for. (e.g. [30]: low VSH in commercial control colonies) [32, 45-48].

\section{Recapping}

In experiments to measure VSH it has often been observed that pupae infested with Varroa that had been uncapped were recapped without the host pupa being injured [30, 31, 49-54]. Although the foundress mite may escape an uncapped brood cell before it is recapped, she usually remains within the cell $[31,50]$. Brood exposed for one week to bees selected for VSH often have high mean percentages (>30\%) of recapped brood cells $[54,55]$, and some colonies may have $>90 \%$ of all brood recapped. Most of these recapped cells are not infested by Varroa, but about $20 \%$ of recapped cells contain a mite [55]. Martin et al. [56] consider recapping as the repair of cells erroneously opened by VSH bees.

Harris et al. [57] suggested that it is possible that hygienic uncapping followed by recapping of brood cells could inhibit or alter mite reproduction. This would be an alternative explanation for the increased percentage of non-reproductive mites found by Harbo \& Harris [34, 36], who did not discriminate between normally capped and recapped cells. This hypothesis was tested by Harris et al. [38]. They found that the frequency of pupae with remaining fertile mites in normally capped brood cells for control bees was $10 \times$ that found for VSH bees, confirming Harbo \& Harris [34, 38] conclusion that VSH 
bees preferentially target cells with reproducing mites. The total number of offspring for fertile mites did not vary between normal and recapped cells, indicating that offspring were not removed before cells were recapped. Mortality of mite offspring was significantly higher in recapped cells than in normally capped cells and contributed to decreased reproduction by the mites [38].

Harris et al. [38, 57] considered recapping to be part of VSH behaviour. However, in the colonies labelled as $\mathrm{VSH}$, not all bees exhibited VSH behaviour, as part of the workers were from patrilines not expressing VSH. Therefore, it could also have been non-VSH bees that recapped the cells opened by de VSH bees. Evidence that non-hygienic bees recap cells comes from Spivak \& Gilliam [24]. When they added young non-hygienic bees to hygienic colonies, hygienic behaviour was suppressed. In a different experiment, they showed that non-hygienic bees tended to recap partially uncapped cells containing dead brood, whereas hygienic bees never recapped those cells. De Guzman et al. [58] found higher recapping rates in Italian bees with low rates of VSH behaviour, than in the resistant Russian honeybees that displayed high rates of VHS. More evidence comes from Boecking \& Spivak [49], who found that bees from pre-selected non-hygienic colonies tended to recap partially uncapped cells that contained freeze-killed brood and from Arathi et al. [52] who demonstrated that in mixed colonies, as compared to a colony of hygienic bees, a higher proportion of uncapped cells were subsequently recapped, resulting in delayed removal of dead brood.

Hence, recapping by non-hygienic bees appears to counteract the activity of the hygienic workers and probably reduces the efficacy of hygienic behaviour against Varroa. More information is needed to know how this depends on the ratio between non-hygienic and VSHbees in a colony.

\section{Measuring Varroa-sensitive hygiene}

Many studies have used frozen or pin-killed brood to assess the rate of removal of pupae infested with Varroa. These assays measure hygienic behaviour, which, as we have seen, correlates only partly with VSH behaviour. Therefore, VSH should be measured using brood infested with Varroa.

\section{Grooming}

\section{Auto- and allogrooming}

As in other insects, adult bees clean their bodies by grooming themselves ("auto-grooming"). As mentioned above, they may also perform a grooming dance to solicit grooming by other bees. Grooming by other bees is called "allo-grooming". This behaviour has been described in detail by Land \& Seeley [59]. Auto and allogrooming are performed by all honeybees to remove dust or pollen. Auto- and allo-grooming in response to the presence of a Varroa mite play important roles in the resistance of $A$. cerana against Varroa [60-62]. In A. cerana hives, $73.8 \%$ of fallen mites exhibited damage [60]. The evidence is based on direct observation of the grooming behaviour in combination with data on the rate of successful mite removal from bees, the percentage of mites dropping to the bottom board and the percentage of damaged mites. It points to a direct relationship between grooming behaviour and the falling of mites to the bottom board. The Varroa mites in the Peng et al. [60] publication originated from A. mellifera. This may have resulted in a higher percentage of damaged mites than if the A. cerana bees had been tested with mites from conspecifics.

\section{Incidence of grooming against Varroa in A. mellifera}

Grooming behaviour against Varroa in A. mellifera is expressed at a lower frequency and intensity than in $A$. cerana $[8,62]$. Depending on subspecies or on differences between colonies of the same subspecies A. mellifera adults vary in response to being mounted by a Varroa mite. They may or may not react by autogrooming or by performing the invitation-to-grooming dance. A. mellifera bees from colonies that are resistant to Varroa show more vigorous and more effective grooming responses $[63,64]$, but good data on the relation between grooming and mite mortality are not available.

\section{Measuring the incidence of grooming behaviour}

Grooming against Varroa mites has been associated with higher proportions of mutilated mites falling from bees in colonies [65] and the proportion of mutilated mites was associated with lower infestation levels [65-68]. Moosbeckhofer [67] found a significant negative correlation between the proportion of dark damaged fallen mites and brood infestation rates. Apis mellifera colonies with the lowest rate of mite population growth showed more grooming behaviour, more mites falling to the hive floor, higher proportions of fallen chewed mites, and reduced infestation levels of adult bees [65]. These observations have been the basis for using the proportion of damaged mites as a measure for grooming behaviour and the belief that it may be a useful parameter in selecting for Varroa resistance.

The proportion of damaged mites fallen to the hive floor varies greatly between colonies and between subspecies: Colonies of $A . m$. ligustica showed an average mite damage rate of $5.75 \%$. In contrast, Rosenkranz et al. [69], working with A. m. ligustica and A.m. carnica, recorded mite damage rates averaging 45\% (44-62\%), while Africanized A. mellifera damaged 38.5\% [70]. Ruttner [71] and Ruttner and Hänel [66] provided evidence 
for active defence of some surviving colonies of $A . m$. carnica against phoretic Varroa, based on the observation of fallen mites with damaged legs and cuticle of the dorsal shield, or idiosoma. Later it was reported [72] that these strong A. $m$. carnica hives eventually achieved a damage rate of $93 \%$. Apis m. mellifera has not been as well studied as the above-mentioned subspecies, but a Polish population of A. m. mellifera bees was much more reactive to Varroa mites than bees from local populations of A. m. carnica and A. m. caucasica: $98 \%$ showing some response to contact with a mite [73].

The question is whether the variation in the proportion of damaged mites reflects heritable variation in grooming behaviour against Varroa mites. Moosbeckhofer [67] reported that $53.7 \%$ of the mites that had fallen to the bottom in the A. m carnica colonies he studied were light-coloured young females, 27.1\% of which were damaged. Such light-coloured females may well have originated from cells after eclosion of a young parasitized worker bee. However, they could as well have originated from cells opened by workers showing VSH behaviour and have been removed with the parasitized pupa or during tidying up of the cell after removal of the pupa. Supporting evidence for the latter scenario comes from Hoffman [74], who assessed damage rates in fallen mites in relation to the development of the brood nest. When no brood was emerging, the damage rate was $10.2 \%$, but was significantly higher at $16.7 \%$, with emerging brood, when the multiple injury rate of mites was also higher. Lobb and Martin [75] estimated that around $50 \%$ of fallen dead mites die within sealed brood cells, the rest mainly shortly after emergence. Martin [76] reported that numbers of fallen mites increased by a factor of 6 [75], or 7-15 [77] when A. mellifera brood was emerging, compared to when it was not. Rosenkranz et al. [69] monitored the proportion of damaged mites in the floor debris of A. mellifera hives with and without emerging brood and when Varroa-sensitive hygiene was stimulated by the insertion of newly killed, but otherwise intact Varroa mites. They found that dead mites removed from brood cells by the bees were damaged to a similar extent as those removed by grooming, which was maximal when brood was emerging. Likewise, Kirrane et al. [48] found that mite-fall was positively correlated with VHS behaviour in Russian honeybees. Hence, a considerable proportion of the fallen and the damaged mites could result from VSH or cell cleaning activities (Fig. 1). Moreover, dead mites could also have been damaged by other organisms scavenging in the hive debris, like wax moth larvae or ants. Andino \& Hunt [78] showed that grooming activity does correlate with the proportion of fallen damaged mites, but explains only $23 \%$ of the variance. Thus, the percentage of damaged mites is not a reliable indicator of the extent of successful grooming taking place.

\section{Other methods to measure and quantify grooming behaviour}

There are additional methods to assess grooming behaviour in response to Varroa: direct records of grooming in observation hives [79], bioassays with frame with several hundreds of bees [78], and bioassays with individual bees or small groups of bees in Petri dishes [64, 80, 81].

Of these, direct observations using an observation hive resembles a natural setting. Also, it measures grooming effort and its success directly, avoiding the problems of interpretation associated with mite fall data. The method is unfortunately time-consuming, which has been the reason for the more common use of simple bioassays with isolated bees in Petri dishes [64]. These bioassays are useful to measure differences in the rate of grooming behaviour between different bee populations. These do not, however, provide a measure of mite mortality. Mites dislodged from the bee's body by grooming fall on the bottom of the Petri dish and can remount the bee [64]. On a vertical frame, mites dislodged from bees may fall to the bottom of the hive. Simple bio-assays are also not suitable to measure allo-grooming frequency. The frequency of mite body injuries showed no correlation with bees' auto-grooming capacity [82]. This suggests that most injuries to mites are likely to be caused by an activity other than auto-grooming per se, e.g. during allogrooming, hunting of non-phoretic individuals or by VSH. Therefore, data obtained by observing isolated bees in Petri dishes, as has been proposed [64] as an assay for grooming, may be un- or weakly related to mite fall and percentage damaged mites in a colony.

Andino \& Hunt's [78] bio-assay with a single frame still uses mite-fall and proportion of damaged mites to assess effective grooming behaviour. However, they exclude VSH as a source of mite-fall by using a frame with only nectar and pollen and no brood and thus, most fallen mites must have been removed from the adult bees by grooming. Their assay could be a suitable one to measure grooming behaviour, in particular when a variant with a frame with open brood is used. It could be used in a selection programme to increase grooming.

\section{The heritability of grooming behaviour}

Büchler et al. [83] selected for an increased proportion of damaged fallen mites. Although they found an increase after several generations, the estimated heritability was low $\left(h^{2}<0.15\right.$ [84];). They concluded that the heritability was too low to justify the laborious sample collection and processing in a large-scale selection program. Stanimirovitz [85] also measured heritability as 
percentage damaged fallen mites and found a variable but rather low heritability $\left(0,16<\mathrm{h}^{2}<0,42\right)$. Moretto et al. [79] using an observation hive to assess the importance of grooming by direct observation, found an estimated heritability of $h^{2}=0.71 \pm 0.41$.

Büchler et al. [84] concluded, against empirical evidence, that the proportion of mutilated mites in the debris of a colony can be used as an indicator of grooming success under field conditions. As only a fraction of the mutilated mites is due to grooming behaviour, their conclusion that the heritability of grooming is too low to justify a selection programme is not supported by proper empirical data. When properly measured, heritability of grooming behaviour could well be high enough for a successful selection programme to increase grooming.

\section{Importance of grooming as a defence against Varroa}

Grooming against phoretic Varroa mites is the only defence that bees have during the long period in winter when there is no brood nest. Honeybee colonies with a high frequency of effective anti-Varroa grooming could in this way reduce the weakening and mortality of worker bees during winter and reduce the parasite population to a low level before the new reproductive season starts. Including anti-Varroa grooming behaviour in a selection programme for Varroa-resistance could therefore be considered, although we do not know if antiVarroa grooming behaviour is an essential trait for resistance against the mite. Andino \& Hunt's [78] bioassay to estimate grooming frequency would be a good compromise to minimize the laborious sample collection and processing.

\section{Non-reproducing Varroa females: brood effects The hypotheses}

Many studies have found evidence that not all female Varroa that enter a cell reproduce. There are four hypothesis that can explain non-reproduction of foundress mites:

(1) As described above, Harbo and Harris [86] initially interpreted the increased proportion of nonreproduction in the lines selected for Varroa resistance as suppression of mite reproduction by the pupae. It turned out that the removal of pupae with reproducing mites by bees from these lines caused most of the increase in the proportion of nonreproducing mites [34].

(2) However, non-reproduction can also be a trait of Varroa. On its original host, A. cerana, a large proportion of adult female mites enter worker cells but do not reproduce and Boot et al. [3] asked why they would enter the worker brood cells if they do not reproduce there. Apparently, reproduction is not the only reason for mites to invade a brood cell. They may invade worker cells of $A$. cerana to hide in safety from the grooming behaviour of adult bees and so survive periods without drone brood $[8,60$, 61]. In $A$. cerana the drones are produced during only $3-4$ months $[9,10]$. With $A$. cerana drone post-capping development times of 13.5-14 days a single fertile mite would have only approximately three to five reproductive cycles per year. This means that adult mites may spend 8-9 months of the year without opportunity to reproduce [4] and would be exposed to grooming behaviour during this time if they would spend it as phoretic mites.

(3) A third hypothesis is that there is a constraint on reproduction in these mites This could either be because they have not been inseminated or because of other reproductive problems. Martin et al. [87] summarize the published evidence that in Europe 6-24\% of adult Varroa females enter cells but do not reproduce. In an experiment he showed that 8$20 \%$ of male Varroa offspring in worker cells and $10 \%$ in drone cells died before being able to mate. Unfertilized females of Varroa only produce male offspring. A recent finding [88] is that unfertilized females may sometimes mate with their own son and then be able to produce daughters during a second reproductive cycle. Yet, unfertilized females can explain a large part of the observed nonreproduction. Other studies found similar results ( [3]: 12\% non-reproduction; $11-17 \%$ only male offspring). Constrained females may explain most of the non-reproduction of Varroa observed in mitesusceptible colonies.

(4) A fourth hypothesis deals with Varroa-tolerant or resistant bees. Camazine [89] compared Varroa reproduction on European Honeybee and Africanized honeybee. He introduced combs of Africanized and European honey bee larvae into mite-infested Africanized bee colonies. In European honeybees, $75 \%$ of infested brood cells had female mites that reproduced, while in Africanized honeybees this was only $49 \%$. As only the origin of the brood was different in his experiment, a factor in the brood apparently affected the reproductive success.

Harbo \& Harris [90] found that the increase in the proportion of non-reproducing mites by VSH could not explain all non-reproduction. A second trait contributed to this reduction: a genetically based factor from the brood produced by VSH queens reduces mite reproduction [34, 91]. Thus, in these selection lines, VSH is not the only mechanism resulting in a reduction of mite reproduction. Three studies now provide 
evidence that the mites do not always reproduce after entering a drone cell, and that there are genetic differences between the drones on which mites reproduce and drone brood on which they do not [92-94] (Fig. 1).

The inhibition of Varroa's reproduction by infested pupae, (i.e., a brood effect) is a shared trait of many Varroa-resistant $A$. mellifera populations across the globe as well as in the original host $A$. cerana $[4,6,47,95-100]$.

\section{The mechanism causing non-reproduction}

Stage specific signals of the host larvae initiate and disrupt Varroa reproduction [101]. Camazine [89] suggests a lower level of juvenile hormone $(=\mathrm{JH})$ production in Africanized bee larvae as hypothesis to explain the lower proportion of reproduction of Varroa in Africanized honeybees. The available evidence published at the time [102, 103] showed that $\mathrm{JH}$ titre indeed affects reproduction in Varroa. It was hypothesized that this hormone could also regulate oogenesis in Varroa, and, in addition, that host-derived JH could be responsible for initiation of reproduction [102]. When more sensitive techniques were available to measure $\mathrm{JH}$ titres, follow-up studies $[104,105]$ could not confirm these results. More recently, Conlon et al. [93] found evidence that a gene from the ecdysone pathway could be involved in the suppression of reproduction of Varroa. Varroa requires ecdysone and pupal proteins to initiate vitellogenesis but lacks the genes for ecdysone synthesis [106]. Other chemical signals than ecdysone emitting from the larva could be involved in inducing the Varroa mite to enter a cell [107], or, inducing Varroa to start reproduction [94]. Understanding the underlying physiological processes that interfere with the crosstalk between the mite and the host larva will be fundamental to comprehend exactly how the brood effect works [108].

Villa et al. [109] tried to increase suppression of Varroa reproduction by selection for the brood effect. They found a significant response during the first two generations of selection but the difference between selected colonies and control colonies disappeared in successive generations. A possible explanation for this finding is that adaptation of mites to host cues occurs in these experiments.

\section{Other brood effects}

Varroa-infested brood from hygienic colonies was more likely to be removed than brood of unselected colonies in cross-fostered brood experiments [110], showing that a factor in the brood is involved in VSH behaviour and mediates Varroa resistance. Hence, brood effects and VSH are partly interdependent (Fig. 1). Signal production by parasitized pupae and perception by the adults can both play roles in the detection of infested cells.

\section{Brood cell size}

The natural cell sizes of European-honeybees (A. mellifera) were smaller than nowadays found in most bee hives. Beekeepers wanted more productive bees and started to use foundation with larger cell sizes, as this was believed to improve colony performance [111]. Erickson et al. [112], however, suggested that the natural, smaller cell size might be advantageous for a number of reasons, including resistance against Varroa. Their hypothesis followed from the observation that Africanized honeybees build small cells (diameter 4.5-4.8 $\mathrm{mm}$ ) in comparison with those of European bees (diameter 5.1-5.5 mm) [89], and that Varroa has a much lower reproductive success in Africanized bees. Independent tests of Erickson et al.'s [112] hypothesis, using a variety of different experimental designs and a variety of criteria to judge the hypothesis have produced variable results. Heaf [113] provides a review of these studies. He cites 15 studies, of which five provide support for the hypothesis by Erickson et al. [112] hypothesis.

One hypothesis to explain a lower reproductive success of Varroa in smaller brood cells is that bees in smaller cells have a shorter developmental time, leaving less time for reproduction of Varroa. A second hypothesis is that immature mites may experience difficulty developing in small cells due to lack of space, impeding movement of the mites and possibly causing an increase in mortality of mother mites and offspring.

\section{Population growth of Varroa}

Martin \& Kryger [114] found evidence in support of this hypothesis when they compared the number of offspring per cycle of Varroa in brood of A. m. scutellata with that in brood of the larger A. m. capensis bees in A. m. scutellata cells. Seeley and Griffin [115] compared bees of the same origin that were either placed on frames with small $(4,8 \mathrm{~mm})$ or large $(5,4 \mathrm{~mm})$ cells. They measured population development of Varroa once a month-from midJune to mid-October and did not find differences in population growth of the mites. They attributed the lack of differences to the small difference in available space between the two types of cells, caused by differences in size of bees developing in small and large cells. Likewise, no larger Varroa populations were found in hives with large cells [116-119].

\section{Number of offspring per cycle}

Although in choice experiments smaller brood cells have a smaller probability of being colonized by Varroa foundresses [117-120], no effect of cell size on the number of female Varroa offspring was found.

Hence, neither the hypothesis that shorter developmental time of bees in small cells results in slower populations growth of Varroa, nor for the hypothesis that lack of space in small cells restricts Varroa reproduction is supported by experimental results. All the evidence that small cells reduce Varroa populations growth come 
from experiments with African or Africanized bees [114, 116, 120, 121]. Maggi et al. [120] found that Varroa was more often non-reproductive in cells with a smaller width. This suggests that the effect is caused by an interaction between cell size and another resistance trait, as explained in the following paragraph.

\section{Interaction between cell size and VSH}

A possible explanation for the variable outcome of studies on small cell size is an interaction between cell size and VSH behaviour. Smaller cells may enhance brood signalling, i.e. in smaller cells suppression of Varroa reproduction by the worker larva, or recognition of cells with reproducing Varroa could be easier. Evidence for this hypothesis comes from [122]. Some of the selection lines that were used did not show the VSH-trait, and provide evidence that cell-size per se does not influence Varroa population growth. In selection lines with the VSH trait the rate of the VSH cleaning behaviour was higher on the smaller cell size. This confirms earlier findings [123]. Hence, the variable outcome of studies on small cell size could be caused by variation in VSH behaviour of the bees used in the different studies (Fig. 1).

\section{Resistance and tolerance against the Varroa-associated viruses}

An important reason why Varroa-infested colonies collapse is that Varroa activates an infection by Deformed Wing Virus (DWV) and increases the titre of other viruses such as Sachbrood virus and Black Queen cell viruses. The latter two have also been implicated in Varroa-induced bee mortality [124].

These viruses have been associated with the death of millions of European honey bee colonies across the world. Bees in the absence of such viruses can sustain much larger Varroa populations before collapse than bees exposed to the virulent forms of these viruses, as was observed in South Africa [125]. The interaction of Varroa with the DWV-honeybee interaction somehow resulted in the virus becoming much more virulent [126], although this has not happened in the honeybee population on the island of Fernando de Noronha in Brazil, [126]. Varroa surviving bees in the Swindon honeybee conservation project also were predominantly infected with an a-virulent type of DWV [127]. Vertical transmission favours the evolution of lower virulence $[128,129]$. As vertical transmission is more frequent in closed populations, it is expected that dominance of the avirulent form of DWV is found on islands, as Fernando de Noronha [126], or otherwise isolated populations, like Gotland [129], Arnot forest [128], Swindon [127]. In addition to lower virulence of the parasite, increased tolerance/resistance of the host is also favoured in a system with predominantly vertical transmission. Evidence for the role of virus tolerance in the Gotland population comes from [130-132] and [133]. Likewise, A. m. scutellata seems resistant or tolerant to DWV [134].

The evolution of lower virulence in DWV and other viruses is also favoured by VSH. The hygienic bees preferentially target pupae that have been damaged by a virulent form of the virus [135], and so can be instrumental in making a less virulent type dominant (Fig. 1).

\section{Bee life-history traits that may hamper Varroa population growth}

Colony size and swarming frequency are life-history traits of bees that affect population growth of Varroa. Although these traits are to some extent heritable, they are largely determined by environmental factors like nest size and food abundance.

The mechanisms whereby smaller and more frequently swarming colonies have greater resistance to $V$. destructor include having relatively few brood cells, especially drone brood, which limits reproductive possibilities for the mites. Frequent swarming also helps control the mites because a swarming event exports about 35\% of a colony's mites [136]. Furthermore, swarming temporarily deprives the mites of brood, and its absence disrupts the mites' reproduction and increases their exposure to grooming. Feral bees in Arnot Forest N.Y. were infested with Varroa mites but had a stable population size with established colonies having a lifespan of 5-6 years [128]. Seeley [137] and Loftus et al. [136] tested the hypothesis that persistence of these wild colonies is at least partly due to their habit of nesting in small cavities and swarming frequently by comparing colonies in small and large hives. These results confirm that smaller nest cavities and more frequent swarming of wild colonies contribute to their persistence without mite treatments. In addition, Seeley and Smith [138] showed that crowding of beehives in apiaries increased Varroa transmission between colonies. They concluded that the scattered distribution of wild colonies makes them less exposed to horizontal infection from other colonies by drifting and robbing as occurs in apiaries [139]. This also contributes to the persistence of these colonies.

\section{Honey bee mating system and population structure and natural selection}

In eusocial insects there is strong selection for increased genotypic diversity in worker offspring to either meet the demands of different tasks or to mitigate the effects of parasitism. Although all workers in a bee colony stem from a single mother, i.e. the queen, genetic variation among workers can be increased by two mechanisms. One of them is to increase the rate of recombination, the other is by polyandry. Indeed, the rate of recombination in honeybees is among the highest measured in 
the animal kingdom [140] and honeybee queens are extremely promiscuous. There is strong evidence that the genetic diversity that a polyandrous queen generates in her colony benefits its members by enhancing workforce productivity [141-143]. As honeybees have single locus sex determination, the high genetic diversity is also important to prevent homozygosity in the sex-alleles, which results in non-viable diploid males instead of worker bees or queens.

Honeybee queens mate in flight [144] with 7-28 drones $[145,146]$, which may originate from colonies up to $15 \mathrm{~km}$ away [147]. Young virgin queens leave the colony for a mating flight. In honey bees the mating system is characterized by "drone congregation areas" (DCA's) that are visited by males from many colonies. Baudry et al. [148] estimated that the drone aggregation area they studied attracted drones from 238 different colonies. Jaffé et al. [149] found lower numbers in a study of A. m. scutellata in South Africa. The number of colonies from which drones arrive in a particular DCA depend on the density of colonies in the area and on the presence or absence of physical barriers (e.g. bodies of water or mountains). Given the high promiscuity of queens, the long distances travelled by queens and drones and the large numbers of colonies from which drones in a DCA originate, the conclusion must be that honeybees have a panmictic population structure. This mating structure is important for how natural selection or selective breeding for Varroa resistance proceeds when queens are allowed to mate freely. While selective breeding and natural selection favour resistance traits, mating of young queens with drones from the surrounding populations counteracts the effects of local selection.

\section{Natural selection for Varroa resistance: the evidence}

As documented in the first part of this review, A. mellifera possesses a number of heritable traits that contribute to its resistance against Varroa. Given the high mortality that Varroa inflicts on non-resistant colonies, it is expected that natural selection upon invasion by Varroa would quickly select for increased frequencies of the resistance traits.

\section{Resistance of a. m. Scutellata and A. m. capensis in South Africa}

Varroa was discovered in South Africa in 1997, where it was most likely introduced with a commercial transport of bees and queens. Two sub-species of honeybee are found in South Africa: the Cape honeybee (A. m. capensis), a coastal race occurring in the fynbos biome along the southwest and south coasts of South Africa [150], and the Savanna honeybee $(A . m$. scutellata) in the rest of South Africa. The mite spread rapidly and after five years was found throughout the country. During peak infestations on average 10,000-17,000 mites could be found in a single colony, and sometimes even 30,000-50,000 mites [125]. Evidently, there was no immediate impediment to Varroa mite reproduction in African Cape and Savanna honeybee colonies and the mite was able to reproduce very efficiently in in both bee subspecies, at least initially. At the peak of the infestation $30 \%$ of colonies collapsed. There was, however, no population-wide collapse of colonies and the majority survived [125]. The tolerance of Cape and Savanna honeybees for higher infestation rates is likely to be due to the absence of deleterious virus outbreaks (e.g. by a virulent form of deformed wing virus) in the South African bees [134]. Although a number of bee viruses have been found in South and East Africa [151, 152], and Cape honeybee pupae and adults were found to be susceptible to virus infections, it was not possible to induce any bee viruses from Cape honeybee colonies, suggesting a general absence of virulent bee viruses in this population [125].

After the peak infestation mite densities gradually decreased and Cape honeybees (A. m. capensis) became resistant 3-5 years after the arrival of Varroa, while Savannah honeybees (A. m. scutellata) became resistant after 6-7 years [125]. To date, Varroa is no longer a problem in South Africa: in Mike Allsopp's words, "Now, it is no more than an arbitrary presence".

Important for the evolution of resistance against Varroa in South Africa was that the original recommendation given to beekeepers that no chemical treatment should be used until it had been ascertained that Varroa would result in honeybee colony collapse. An additional reason why natural selection could work swiftly was the presence of a large wild honeybee population. Hence, natural selection could operate in both commercial and wild bees, unhampered by the widespread use of acaricides.

As only a relatively minor part of the bee population collapsed, mortality by Varroa did not cause a genetic bottleneck that would otherwise have hampered the evolution of resistance.

The following traits have been invoked to explain the resistance (see also Table 1).

(1) Hygienic behaviour [47, 153, 154]. Fries \& Raina [155] report that $77 \%$ of pin-killed brood is removed by $A$. $m$. scutellata in $24 \mathrm{~h}$, a removal rate much higher than reported for European bees [29, 153, 156]

(2) Grooming: [154], measured as the percentage of damaged fallen mites

(3) Non-reproduction: [98, 114]. Reproductive failure has increased over time [157], suggesting that VSH and or a brood effect has increased over time.

(4) Short developmental time. Allsopp [125] concluded that the shorter post-capping stage (between 9.6 and 12 days in Cape honeybees, 10-12 days in A. $\mathrm{m}$. 
Table 1 Traits that have been measured and/or invoked to explain resistance

\begin{tabular}{|c|c|c|c|c|c|}
\hline $\begin{array}{l}\text { Populations } \\
\text { Traits }\end{array}$ & $\begin{array}{l}\text { A. scutellata } \\
\text { \& A. capensis }\end{array}$ & $\begin{array}{l}\text { Africanized bees in } \\
\text { South America }\end{array}$ & $\begin{array}{l}\text { Arnot Forest, } \\
\text { New York }\end{array}$ & Primorsky & $\begin{array}{l}\text { Gotland } \\
\text { Sweden }\end{array}$ \\
\hline Hygienic Behaviour & yes & yes & No evidence & yes & no \\
\hline VSH & yes & yes & Yes & yes & no \\
\hline Grooming & yes & yes & Yes & yes & no \\
\hline Non-reproduction & yes & yes & No evidence & yes & yes \\
\hline Shorter Developmental time & yes & yes & no & no & no \\
\hline Virus tolerance or resistance & possibly & possibly & Possibly, No evidence & no & Yes \\
\hline Life-history \& spatial distribution of colonies & no & no & yes & yes & no \\
\hline
\end{tabular}

scutellata, $[114,158,159]$ can reduce reproductive output of Varroa.

VSH has never properly been measured in South Africa, but is an important trait in the resistance of a Kenyan population of $A . m$. scutellata [47]. Moreover, it plays an important role in Africanized bees in South America [158].

The most plausible way to explain the changes in abundance of Varroa after its arrival in South Africa is that the frequency of resistance genes in the bee populations of $A . M$. scutellata and A. m. capensis were too low to prevent the observed population explosion, but that most colonies survived peak densities of Varroa because they could tolerate high densities in the absence of virulent viruses that otherwise would have destroyed the colonies. Natural selection for resistance against the mites subsequently took over, resulting in an overall low Varroa density.

It is likely that the alleles for the resistance traits i.e. hygienic behaviour and grooming were already present at frequencies higher than found in European honeybees, before Varroa colonized Africa, as Africanized bees showed these behaviours when Varroa arrived in South America.

\section{Resistance of Africanized bees}

In 1957 African A. m. scutellata bees imported from Tanzania into Brazil to improve honey production in tropical South America escaped from an experimental apiary and hybridized with European bees. The hybrids spread in South America and colonized Central America and the southern United States.

Although African honeybees came to Brazil long before Varroa colonized Africa and before the African $A$. $m$. scutellata bees had developed resistance against the mite, the A. m. scutellata hybrids showed already tolerance or resistance to Varroa. Soon after the discovery of Varroa in 1979, the levels of infestations detected were a source of concern for Brazilian apiculture, although there were no reports of bee colony deaths [160]. It soon became clear that Africanized bees can survive Varroa infestation without treatment [153, 158, 161-163]. Rapid natural selection seems to have resulted in increased resistance and treatment against Varroa is generally not practiced. Losses of Africanized honey bee colonies due to varroosis are not reported and possible negative effects on honey production seem to be negligible [160]. This is surprising, as in contrast to South Africa, viruses associated with Varroa like Deformed Wing Virus are widespread in South America [164-166] and Africanized bees are not resistant against the virus [167, 168], although in one study, the rate of virus increase was lower in Africanized bees than in European bees [169].

The Africanized bee is the common race of honeybee in Brazil. An important prerequisite for the rapid evolution of Varroa resistance was the enormous number of feral colonies of Africanized honey bees in Brazil. Even in natural rainforest ecosystems without any beekeeping activities, the honey bee is the predominant pollinator. Obviously, colonies managed by beekeepers represent only a small percentage of Brazil's honey bee population. Therefore, the feral honey bee population is permanently exposed to selection for Varroa resistance. In Mexico, the Africanized honeybee was established for the first time in 1992 and was found to be resistant against Varroa already in 1994. Thus, it appears unlikely that the resistance evolved there and more likely that the bees invading from Brazil were already resistant [170].

The following traits have been invoked to explain the resistance (see also Table 1):

(1) Hygienic behaviour: Africanized bees are generally regarded as having better hygienic behaviour than European bees $[51,68,70]$. found only slightly better hygienic behaviour in Africanized bees, most likely because they worked with artificially recapped cells.

(2) VSH: $[46,171,172]$ and provide experimental evidence that Africanized bees have a higher rate of VHS behaviour than European bees. Although the first two publications precede Harris' [37] 
publication in which VSH was defined, the behaviour described in these papers is clearly VSH.

(3) Grooming: Africanized bees are more efficient in removing phoretic Varroa by grooming than European honeybees [68, 79, 171].

(4) Non-reproduction: Varroa shows a higher rate of non-reproduction in the Africanized honeybee from Brazil and Mexico, than in European honeybees $[171,173]$

(5) Shorter developmental time: post-capping period 11.5-11.6 days in Africanised honeybees compared to 11.6-12.0 days in European honeybees [174]

\section{Survival of feral honeybees in Arnot Forest in New York USA}

Varroa arrived in the U. S in the mid-1980s. A feral population of bees breeding in hollow trees had been censused in 1978, prior to the introduction of $V$. destructor to North America [175]. The census was repeated in 2002 when Varroa had established itself [128]. The number of bee colonies in the forest had not changed. Swarms from this feral population were trapped in the forest and placed in hives to study if the colonies suppressed the Varroa mites. In 2005, no differences in mite population growth were found between the feral bees and commercial non-resistant A. m. carnica bees. It is possible that the relatively short period of time during which the bees of the Arnot Forest had been exposed to Varroa is the reason that alleles for resistance traits had not yet increased, but that the bees persisted because of small colony sizes [138], frequent swarming and the widely spaced colonies [137]. An untested additional hypothesis is that mites and/or the viruses vectored by them may had become less virulent. When colonies are widely separated, their parasites and pathogens are probably transmitted mostly vertically (from parent colony to offspring colony) through swarming, a scenario that selects for decreased virulence [128]. Another possibility is that the Arnot Forest bees were Varroa tolerant because they had evolved tolerance or resistance against the associated viruses, as was found for a Swedish population [130]. Ten years later, genomic data showed that mayor genetic changes had occurred since 1978 [176] and convincing evidence for Varroa-resistance in the Arnot Forest honeybee population was found [177]: the feral bees from Arnot Forest are able to reduce mite populations by increased grooming and VSH behaviour.

\section{Selection for resistance in Prymorski bees}

European settlers took A. mellifera (spp. caucasica $\mathcal{E}$ carnica) in 1865 to far eastern Russia (Primorsky) [178, 179]. The area has native $A$. cerana infested with $V$. destructor which most likely infested the arriving A. mellifera, resulting in the longest known association of $A$. mellifera and $V$. destructor $[1,180])$. Preliminary examinations of $A$. mellifera in the Primorsky territory suggested that they might have substantial levels of mite resistance [180]. These observations inspired the importation of 362 preselected queens into North America from 1997 to 2002 [181] for further testing of these Primorsky honey bee queens and the start of a selection programme in the USA for Varroa resistance by colonylevel selection [182]. An initial evaluation indicated that their commercial traits such as honey production were similar to those of existing commercial stocks [183]. Most importantly, some of the imported Primorsky queens produced colonies which appeared to be resistant to $V$. destructor [183]. After eight years of selection several Primorsky queen lines show mite population growth $<1$ and thus were Varroa resistant [184]. The other lines had growing Varroa populations and some of them did not much better than commercial Italian bees. Further selection decreased the variance between lines and resulted in overall resistance in the Russian bees [58, 185]. The resistant Primorsky bees exhibited strong grooming traits [1], high hygienic behaviour, VSH [48], reduced brood attractiveness for Varroa, and decreased reproductive success of Varroa in combs built by the Russian honeybees [186] (See also Table 1). Unlike Italian colonies they either slow down or completely stop brood production in response to a lack of nectar flow [187]. This resource sensitivity may also contribute to Russian honey bees' Varroa resistance by interrupting Varroa reproduction.

Hence natural selection in eastern Russia had resulted in a high but variable presence of resistance traits. Artificial selection at colony level in the US in isolated mating yards resulted in fully resistant Russian bees. The use of isolated mating yards has prevented the loss of resistance alleles by the dilution effect of the panmictic mating structure, and a well-designed breeding schedule prevented the loss of genetic variation.

\section{Resistance in European bees}

Unlike A. m. scutellata and A. m. capensis in Africa and the A.m. scutellata hybrids in South America, European subspecies of bees suffered massive colony collapse upon the arrival of Varroa from Russia. The new parasite devastated natural populations of A.mellifera in Europe and feral populations in North America, and beekeepers experienced massive mortality of colonies. They had no other choice than using acaricides, organic acids or essential oils to kill the mites, thus hampering natural selection for resistance. Other apicultural practices that are unfavourable for the evolution of Varroa resistance are: crowding together of colonies in apiaries, so that horizontal transmission of Varroa is favoured; managing colonies to be unnaturally large, so that they have high 
honey production and low swarming rates; moving colonies from place to place, so that there is strong gene flow that prevents natural selection from altering locally adaptive allele frequencies in a closed population; and regular re-queening of colonies with pure-bred nonresistant queens. All these practices contribute to making apiaries an ideal environment for Varroa mites and the viruses they vector.

In Europe and North America, resistance traits are present, albeit at a low frequency in the population and their expression inside colonies is reduced by the bees in a colony that do not have the resistance alleles [188]. The presence of resistance alleles has been shown by efforts to select for increased hygienic behaviour [24], grooming [73], VSH and suppressed mite reproduction [110]. However, the expression of resistance alleles in the European honeybee populations is not strong enough to prevent the Varroa population to grow and to prevent colonies from collapse. Natural populations of A. mellifera, and the pollination afforded by them, have largely been eliminated by the mite in Europe [100], threatening the majority of the ten European subspecies with extinction and making that natural selection for Varroa resistance cannot proceed in populations not submitted to apicultural practices.

Yet, a number of European studies discovered colonies and populations of honeybees that survived the invasion of Varroa without treatment against the mites (Table 1). Surviving bees were found in Yugoslavia [189]. Starting with three colonies that survived an epizootic of $V$. destructor, a stock of honey bees was produced which was only slightly more resistant than other stocks. Surviving populations were also found in France [190] and in Norway [99]. Other studies report the importation of bees known to be already Varroa-resistant and their survival without treatment after importation and hybridisation with local bees: A. m. intermissa imported from Tunisia [191, 192] and surviving bees from Gotland, Sweden [81, 193] for one of their populations.

In addition, there is one well-documented large scale experiment with a population of untreated colonies kept without treatment [129]. These studies claim that sometimes local conditions allow the evolution of Varroa resistance by natural selection. In the following we will explore why evidence for the evolution of resistance in Varroa in Europe is rather scanty.

Fries et al. [129] founded a genetically diverse honey bee population of 150 colonies on a peninsula at the southern tip of the island Gotland in the Baltic sea, isolated from the main island through a narrow land bridge. Swarms produced were added as new colonies to the population. After four years, 38 new colonies had been established from swarms, but mortality due to Varroa infestation resulted in only 13 colonies of the 188 surviving after four years. The colonies surviving after four years had mite infestations that were more than halved in comparison with the third year, before massive colony collapse occurred. In addition, surviving colonies had fewer worker-bees and produced fewer drones [194, 195]. The small number of colonies surviving resulted in a genetic bottleneck and strong inbreeding [107]. The experiment shows that genetic variation for resistance was present in the population before selection and that natural selection to improve Varroa resistance is possible in closed populations, albeit at a price of lower brood production.

Le Conte et al. [190] collected 82 colonies that had survived the invasion by Varroa without treatment. They were placed in the region where they had been found: 30 in an apiary near Le Mans, and 52 in an apiary in Avignon. Treated control colonies were placed nearby. The mortality of colonies varied between 9.7 and $16.8 \%$ per year. Surviving colonies had only $32.4 \%$ of the Varroainfestation rate in control colonies. Honey production by untreated surviving colonies was half of that of the controls. The experiment shows that the collected colonies had some degree of Varroa resistance at the start of the study. The surviving colonies were maintained under artificial selection as is witnessed by this citation [196]: "What has happened to these bees since we published those results in 2007? Once every two years, we graft queen larvae from the three best colonies in each apiary (west and south of France) to get 20 colonies. The queens are naturally mated by local drones. About $30-35 \%$ of the colonies die within 18 months, but the rest of the colonies are good candidates for surviving to the mite, so the stock still survives efficiently". Hence, despite continued selection, Varroa resistance has not increased over a 10year period.

The natural and artificial selection for colony survival did not increase the frequency of resistance genes probably because the bees are kept in an open panmictic breeding population. While selection favours colonies with a higher frequency of resistance alleles, panmictic mating in a population with a low frequency of these alleles makes that queens of the selected colonies mate with drones with a low frequency of the resistance alleles, In addition, drones with resistance genes from the untreated colonies disperse into the environment. Thus, the mating structure of the population counteracts local selection for Varroa resistance.

Colonies descending from both the Avignon and Gotland survivor populations both still harboured growing mite populations with more than 0.7 fertile female offspring per foundress per cycle, and would have collapsed if left to natural selection alone [162]. They survived because they were subjected to prolonged artificial selection and periodically multiplied by breeding a large 
number of queens from the best colonies [194, 196]. When the Avignon bees were tested outside their native environment in a Europe-wide experiment [197], neither their Varroa infestation rate after one year without treatment nor their survival outperformed that of colonies descending from non-selected genotypes tested at the same locations.

The surviving colonies from the Østlandet region in Norway were part of an open panmictic breeding population ("the population being within sufficient distance of known susceptible colonies from various backgrounds (mostly A. m. mellifera, A. m. carnica, Buckfast) that would facilitate horizontal parasite transfer" [99]). These colonies were also multiplied by splitting the healthy surviving ones to replace lost colonies [99] and hence they were also under a continuing regime of artificial selection. The surviving colonies harbour growing mite populations ( 0.87 fertile female offspring per foundress).

Which mechanisms are involved in reducing mite reproduction in these populations? The role of hygienic behaviour was investigated in the surviving Gotland colonies by studying the fate of 100 pin-killed pupae [195]. Removal rate in $12 \mathrm{~h}$ was only $15 \%$ and not different from the $20 \%$ found in control colonies, not supporting a role for hygienic behaviour. Unfortunately, the authors did not test for VSH behaviour, leaving the possibility that the removal of mite infested pupae plays a role in reducing Varroa reproduction. They also measured the percentage of damaged mites of mites fallen onto the bottom board. As we have seen above damaged mites can both result from VSH behaviour as well as from grooming behaviour. They found 31-35\% of damaged mites, which was not different from the percentage found in unrelated control colonies. Although the results are not supporting the hypothesis that grooming plays a role in the reduction of the Varroa population, they cannot be taken as evidence that grooming plays no role. Experiments using a better assay to assess grooming, e.g. that of [78] are needed. The surviving Gotland colonies had a significantly lower proportion of mites that reproduced successfully ( $48 \%$ versus $78 \%$ in control colonies) [195]. Failure to reproduce resulted from infertility, absence of male offspring, high proportion of mite offspring mortality, or delayed egg-laying by the mother mite. As we have seen, there are four possible mechanisms to explain an increased percentage of nonreproduction in Varroa, two of which caused by the bees, i.e. VSH behaviour and a brood effect. Proper experiments on VSH behaviour and a brood effect are needed to distinguish between these hypotheses. As the resistant bee populations originated from only 13 surviving colonies, it is possible that traits like VSH and grooming were not present in the small sample. Locke and Fries [195] suggested that the smaller colony size of the surviving bees is an adaptation that would reduce reproductive rate of Varroa. As smaller colony size decreases colony fitness in many ways, we prefer the alternative hypothesis that the smaller colony size is non-adaptive and an effect of inbreeding in this population.

They also suggested that the Gotland bees were resistant to viruses that normally cause colony collapse. This was confirmed by [130-132] and [133]. Why did the Gotland experiment not result in fully resistant bees? As only 13 of 188 colonies survived, and genetic drift had caused an extreme loss of genetic diversity in the surviving population, it seems likely that insufficient genetic variation hampers the evolution to full resistance in this population. This hypothesis should be tested by increasing the genetic variation in this population and document the changes in mite reproductive success.

The Varroa mites in colonies of the Avignon population of surviving bees also had a lower proportion of reproducing mites, with non-reproduction being the most important factor [198]. The mechanism causing the reduction in reproduction was not determined. VSH could possibly explain the supressed mite reproduction in this population, as genetic evidence suggests that the suppressed mite reproduction is caused by a behavioural trait [199]. The mechanism of resistance in the Le Mans population has not been studied (See also Table 1).

Reduced reproductive success of Varroa was also observed in the surviving colonies from the Østlandet region in Norway [99]. This cannot be completely explained by VSH behaviour as the frequency of VSH was only $5 \%$. Oddie et al. [200] suggested that a slightly shorter post-capping period for the brood of surviving colonies in comparison with non-related controls could have contributed to the lower Varroa reproductive rate, but did not calculate whether this small difference could produce the observed effect on mite reproduction, which seems unlikely. Other mechanisms, like a brood effect were not studied.

Kefuss [191, 192] started Varroa-resistant lines by importing A.m. intermissa from Tunisia. Judging from the very high rates $(40-75 \%)$ of non-reproduction in these bees they had already a high incidence of VSH behaviour when arriving in France. Evidence for high rates of VSH and grooming in these bees is provided by [62, 201]. In a Dutch experiment on survival of untreated bee colonies Panziera et al. [193] found evidence for the role of VSH in reducing mite populations.

None of the European studies cited above have resulted in a fully Varroa-resistant population. This is either because surviving colonies were part of a panmictic population and surrounded by colonies with low frequency of resistance traits, or, in the only example of a closed population (Gotland), because of inbreeding. 


\section{Conclusions}

The host shift of Varroa destructor to Apis mellifera and the fast colonization of $A$. mellifera populations in Europe, the Americas and Africa initially resulted in considerable mortality exerting strong selection for the evolution of resistance against the mites. While selection resulted in resistance in populations of A. mellifera scutellata and A. m. capensis in Africa and in A. m. scutellata hybrids in South America, resistance did not evolve in honeybees in Europe and North America. Most unprotected colonies of European honeybees in these continents succumb when infested with Varroa and resistance to Varroa has not increased in the 40 years after the Varroa invasion.

We have reviewed research on traits for Varroa resistance and the literature that documents the evolution of resistance to Varroa in Africa and in South America. We have also reviewed studies of several populations on honeybees in Europe and North America that were not treated against Varroa and the evidence these studies provide for natural selection of Varroa resistance.

From reviewing this evidence, we conclude that:

(1) Natural selection can result in population-wide resistance in large panmictic populations only when a large proportion of the population survives the initial invasion of Varroa. This is what happened in Africa and South America.

(2) When, upon invasion of Varroa a major part of the bee population collapses or is protected against the mite by chemical treatment, natural selection for resistance does not succeed. This is what occurred in Europe and North America.

(3) Small colony size, frequent swarming and widely spaced colonies of wild or feral honeybees reduce the risk of colony collapse due to Varroa infestation. These life-history and ecological characters promote vertical transmission of mites and viruses are therefore conducive to the evolution of less virulent mites and viruses and more resistant bees. These characters also allow the evolution of resistance in wild bee populations. This is shown by the study of the bees in Arnot Forest.

(4) The panmictic mating structure of honey bees prevents local natural selection for resistance, because resistance genes disperse into neighbouring populations at a rate higher or equal to the local rate of recruitment of these genes by selection.

(5) Selection by breeding can increase the level of resistance of colonies and so increase the proportion of resistant colonies in the population as whole. When this proportion is high enough, bee keepers can stop chemical treatment and natural selection can proceed.
(6) In closed populations, as on islands, natural selection is not counteracted by the dispersal of resistance genes, and natural selection can proceed, unless it is constrained by inbreeding. This is what the Gotland experiment has shown.

In most of the populations that developed resistance against Varroa, behavioural defences against the mites are important: grooming against phoretic mites and hygienic behaviour, or more precisely VSH against reproducing mites. In addition, brood effects and shorter developmental times play a role in reducing Varroa mite reproductive success. The exception is the Gotland experiment, in which no evidence was found for grooming or hygienic behaviour (Table 1). On the whole these results show that natural selection favours traits that also have been used in selective breeding programmes.

The ultimate goal of making European and North American honeybees resistant against Varroa is within reach. Artificial selection using single drone insemination as pioneered by [32] and [86] can be used to increase the frequency of resistance alleles in the honeybee populations of both continents. Natural and artificial selection at colony level can also be used in closed populations (e.g. on islands or otherwise isolated mating yards) providing that genetic variation in these populations is maintained. Resistant colonies produced in this way can then be used to increase the level of resistance in large panmictic populations. Once the resistance level has passed the threshold where it becomes profitable for apiculturists to stop chemical treatments of the mite, natural selection can proceed to make European and North American honeybees fully Varroa resistant.

\section{Acknowledgements}

The authors acknowledge Frietson Galis, Irene Eijs and Sacha d'Hoop for useful comments on earlier drafts of the manuscript.

\section{Authors' contributions}

JVA and BJF both compiled and read the literature used to write the review and interpreted the available data. JVA wrote the first draft of the manuscript and BJF improved and edited it. Both authors read and approved the final manuscript.

\section{Authors' information}

Jacques van Alphen is emeritus professor of ecology, retired from the University of Leiden and currently associated with the Naturalis Biodiversity Centre. He is Chairman of the Arista Bee Research Foundation. This is a foundation for breeding Varroa resistant honey bees. BartJan Fernhout is the program director of Arista Bee Research.

\section{Funding}

Authors did not receive funding for this manuscript.

Availability of data and materials

Not applicable.

Ethics approval and consent to participate Not applicable. 


\section{Consent for publication}

Not applicable.

\section{Competing interests}

The authors declare that they have no competing interests.

Received: 17 November 2019 Accepted: 3 April 2020

Published online: 18 May 2020

\section{References}

1. Rinderer TE, De Guzman LI, Elatte GTD, Telzer JS, Ancaster VL, Uznetsov VK, et al. Resistance to the parasitic mite Varroa destructor in honey bees from far-eastern Russia. Apidologie. 2001:32:381-94.

2. Martin SJ. The role of Varroa and viral pathogens in the collapse of honeybee colonies: a modelling approach. J Appl Ecol. 2001;38:1082-93.

3. Boot WJ, Tan NQ, Dien PC, Van Huan L, Van Dung N, Long LT, et al. Reproductive success of Varroa jacobsoni in brood of its original host, Apis cerana, in comparison to that of its new host, A. mellifera (Hymenoptera: Apidae). Bull Entomol Res. 1997;87(2):119-26.

4. Rath W. Co-adaptation of Apis cerana Fabr. And Varroa jacobsoni Oud. Apidologie. 1999;30:321-9.

5. Lin Z, Qin Y, Page P, Wang S, Li L, Fuliang W, et al. Reproduction of parasitic mites Varroa destructor in original and new honeybee hosts. Ecol Evol. 2018; 8(December 2017):2135-45.

6. Rosenkranz P, Aumeier P, Ziegelmann B. Biology and control of Varroa destructor. J Invertebr Pathol. 2010;103(SUPPL. 1):S96-119 https://doi.org/10. 1016/j.jip.2009.07.016.

7. Moritz RFA, Kraus FB, Kryger P, Crewe RM. The size of wild honeybee populations (Apis mellifera) and its implications for the conservation of honeybees. J Insect Conserv. 2007;11(4):391-7.

8. Fries I, Huazhen W, Wei S, Jin CS. Grooming behavior and damaged mites (Varroa jacobsoni) in Apis cerana cerana and Apis mellifera ligustica. Apidologie. 1996;27:3-11.

9. Tewarson N, Singh A, Engels W. Reproduction of Varroa jacobsoni in colonies of Apis cerana indica under natural and experimental conditions. Apidologie. 1992;23(2):161-71 http://www.apidologie.org/articles/apido/ pdf/1992/02/Apidologie_0044-8435_1992_23_2_ART0009.pdf\%5Cn, http:// www.apidologie.org/index.php?option=com_article\&access= standard\&ltemid=129\&url=/articles/apido/pdf/1992/02/Apidologie_00448435_1992_23_2_ART0009.pdf.

10. Rath W, Drescher W. Response of Apis cerana Fabr towards brood infested with Varroa jacobsoni Oud and infestation rate of colonies in Thailand. Apidologie. 1990;21:311-21.

11. Guzman-Novoa E, Emsen B, Unger P, Espinosa-Montaño LG, Petukhova T. Genotypic variability and relationships between mite infestation levels, mite damage, grooming intensity, and removal of Varroa destructor mites in selected strains of worker honey bees (Apis mellifera L.). J Invertebr Pathol. 2012;110(3):314-20 https://doi.org/10.1016/j.jip.2012.03.020.

12. Mondet F, Alaux C, Severac D, Rohmer M, Mercer AR, Le Conte Y. Antennae hold a key to Varroa-sensitive hygiene behaviour in honey bees. Sci Rep. 2015;5 https://doi.org/10.1038/srep10454.

13. Mondet F, Kim SH, De Miranda JR, Beslay D, Le Conte Y, Mercer AR. Specific cues associated with honey bee social defence against Varroa destructor infested brood. Sci Rep. 2016;6(January):1-8 https://doi.org/10.1038/ srep25444.

14. Park OW. Disease resistance and American foulbrood. Am Bee J. 1936;74:12-4.

15. Woodrow AW, Holst EC. The mechanism of colony resistance to American Foulbrood1. J Econ Entomol. 1942;35(3):327-30.

16. Rothenbuhler W. Behavior genetics of nest cleaning in honey bees. IV. Responses of F1 and backcross generations to disease-killed brood: Walter C. Rothenbuhler Reviewed work(s): Published by : Oxford University Press content in a trusted digital archiv. Am Zool. 1964;4(2):111-23.

17. Lapidge KL, Oldroyd BP, Spivak M. Seven suggestive quantitative trait loci influence hygienic behavior of honey bees. Naturwissenschaften. 2002; 89(12):565-8.

18. Oxley PR, Hinhumpatch P, Gloag R, Oldroyd BP. Genetic evaluation of a novel system for controlled mating of the honeybee, Apis mellifera. J Hered. 2010;101(3):334-8.

19. Harpur BA, Guarna MM, Huxter E, Higo H, Moon KM, Hoover SE, et al. Integrative genomics reveals the genetics and evolution of the honey bee's social immune system. Genome Biol Evol. 2019;11(3):937-48.
20. Woodrow AW, States HJ. Removal of diseased brood in colonies infested with AFB. Am Bee J. 1943;83:22-3.

21. Spivak M, Gilliam M. Hygienic behaviour of honey bees and its application for control of brood diseases and varroa part I. hygienic behaviour and resistance to American foulbrood. Bee World. 1998;79(3):124-34.

22. Gilliam M, Taber S. Microorganisms and diseases encountered in continuous bee production. Am Bee J. 1973;113:222-3.

23. Gilliam M, Taber S, Richardson GV. Hygienic behavior of honey bees in relation to chalk brood disease. Apidologie. 1983;14:29-39.

24. Spivak M, Gilliam M. Facultative expression of hygienic behaviour of honey bees in relation to disease resistance. J Apic Res. 1993;32(3-4):147-57.

25. Spivak M, Gilliam M. Hygienic behaviour of honey bees and its application for control of brood diseases and varroa: part II. Studies on hygienic behaviour since the Rothenbuhler era. Bee World. 1998;79(4):169-86.

26. Taber S. Bee behavior. Breeding for diease resistance. Am Bee J. 1982;122: 177-9.

27. Taber S, Gilliam M. Breeding honeybees for resistance to diseases. Korean J Apic. 1987;2:15-20.

28. Boecking $O$, Dreschner W. Response of Apis mellifera $L$ colonies infested with Varroa jacobsoni Oud. Apidologie. 1991;22:237-41.

29. Spivak M. Honey bee hygienic behavior and defense against Varroa jacobsoni. Apidologie. 1996;27:245-60.

30. Danka RG, Harris JW, Villa JD, Dodds GE. Varying congruence of hygienic responses to Varroa destructor and freeze-killed brood among different types of honeybees. Apidologie. 2013;44(4):447-57.

31. Boecking O, Bienefeld K, Drescher W. Heritability of the Varroa-specific hygienic behaviour in honey bees (Hymenoptera: Apidae). J Anim Breed Genet. 2000;117(6):417-24.

32. Harbo JR, Hoopingarner RA. Honey bees (Hymenoptera Apidae) in the United States that express resistance to Varroa jacobsoni (Mesostigmata Varroidae). J Econ Entomol. 1997;90(4):893-8.

33. Harbo JR, Harris JW. Heritability in honey bees (Hymenoptera: Apidae) of characteristics associated with resistance to Varroa jacobsoni (Mesostigmata: Varroidae). J Econ Entomol. 1999;92(2):5 http://mq.library.ingentaconnect. com/content/esa/jee/1999/00000092/00000002/art00002.

34. Harbo JR, Harris JW. Suppressed mite reproduction explained by the behaviour of adult bees. J Apic Res. 2005;44:21-3.

35. Ibrahim A, Spivak M. The relationship between the suppression of mite reproduction (SMR) and hygienic behaviour. Am Bee J. 2004;144(5):406.

36. Harbo JR, Harris JW. Levels of Varroa sensitive hygiene. J Apic Res. 2009; 48(3):156-61.

37. Harris JW. Bees with Varroa sensitive hygiene preferentially remove mite infested pupae aged $\leq$ five days post capping. J Apic Res. 2007;46(3):134-9 https://doi.org/10.1080/00218839.2007.11101383.

38. Harris JW, Danka RG, Villa JD. Changes in infestation, cell cap condition, and reproductive status of Varroa destructor (Mesostigmata: Varroidae) in brood exposed to honey bees with Varroa sensitive hygiene. Ann Entomol Soc Am. 2012;105(3):512-8 https://academic.oup.com/aesa/article-lookup/doi/1 $0.1603 /$ AN11188.

39. Kim SH, Mondet F, Hervé M, Mercer A. Honey bees performing varroa sensitive hygiene remove the most mite-compromised bees from highly infested patches of brood. Apidologie. 2018;49(3):335-45.

40. Wagoner K, Spivak M, Hefetz A, Reams T, Rueppell O. Stock-specific chemical brood signals are induced by Varroa and deformed wing virus, and elicit hygienic response in the honey bee. Sci Rep. 2019;9(1):1-14.

41. Harbo JR, Harris JW. The number of genes involved in the SMR trait. Am Bee J. 2005;145(5):447-8.

42. Tsuruda JM, Harris JW, Bourgeois L, Danka RG, Hunt GJ. High-resolution linkage analyses to identify genes that influence Varroa Sensitive Hygiene Behavior in honey bees. PLoS One. 2012;7:11.

43. Spötter A, Gupta P, Mayer M, Reinsch N, Bienefeld K. Genome-wide association study of a Varroa-specific defense behavior in honeybees (Apis mellifera). J Hered. 2016;107(3):220-7.

44. Scannapieco AC, Mannino MC, Soto G, Palacio MA, Cladera JL, Lanzavecchia SB. Expression analysis of genes putatively associated with hygienic behavior in selected stocks of Apis mellifera L. from Argentina. Insect Soc. 2017;64(4):485-94

45. Correa-Marques MH, De Jong D. Uncapping of worker bee brood, a component of the hygienic behavior of Africanized honey bees against the mite Varroa jacobsoni Oudemans Corrêa-Marques Jong a. Apidology. 1997; 29:283-9. 
46. Guerra JCV, Gonçalves LS, De Jong D. Africanized honey bees (Apis mellifera L.) are more efficient at removing worker brood artificially infested with the parasitic mite Varroa jacobsoni Oudemans than are Italian bees or Italian/ Africanized hybrids. Genet Mol Biol. 2000;23(1):89-92.

47. Cheruiyot SK, Lattorff HMG, Kahuthia-Gathu R, Mbugi JP, Muli E. Varroaspecific hygienic behavior of Apis mellifera scutellata in Kenya. Apidologie. 2018;49:439-49 http://link.springer.com/10.1007/s13592-018-0570-6.

48. Kirrane MJ, De Guzman LI, Whelan PM, Frake AM, Rinderer TE. Evaluations of the removal of Varroa destructor in Russian honey bee colonies that display different levels of Varroa sensitive hygienic activities. J Insect Behav. 2018;31: 283-97.

49. Boecking $O$, Spivak M. Behavioral defenses of honey bees against Varroa jacobsoni Oud. Apidologie. 1999;30:141-58.

50. Aumeier P, Rosenkranz P. Scent or movement of Varroa destructor mites does not elicit hygienic behaviour by Africanized and Carniolan honey bees. Apidologie. 2001;32(3):253-63.

51. Aumeier P, Rosenkranz P, Gonçalves LS. A comparison of the hygienic response of Africanized and European (Apis mellifera carnica) honey bees to Varroa-infested brood in tropical Brazil. Genet Mol Biol. 2000;23(4):787-91.

52. Arathi HS, Ho G, Spivak M. Inefficient task partitioning among nonhygienic honeybees, Apis mellifera $\mathrm{L}$., and implications for disease transmission. Anim Behav. 2006;72(2):431-8.

53. Villegas AJ, Villa JD. Uncapping of pupal cells by European bees in the United States as responses to Varroa destructor and Galleria mellonella. J Apic Res. 2006;45(4):203-6.

54. Villa JD, Danka RG, Harris JW. Simplified methods of evaluating colonies for levels of Varroa sensitive hygiene (VSH). J Apic Res. 2009;48:162-7.

55. Harris JW. Effect of brood type on Varroa-sensitive hygiene by worker honey bees (Hymenoptera: Apidae). Ann Entomol Soc Am. 2008;101(6):1137-44

56. Martin SJ, Hawkins GP, Brettell LE, Reece N, Correia-Oliveira ME, Allsopp MH. Varroa destructor reproduction and cell re-capping in mite-resistant Apis mellifera populations. Apidologie. 2019; https://doi.org/10.1007/s13592-01900721-9.

57. Harris JW, Danka RG, Villa JD. Honey bees (Hymenoptera: Apidae) with the trait of Varroa sensitive hygiene remove brood with all reproductive stages of Varroa mites (Mesostigmata: Varroidae). Ann Entomol Soc Am. 2010; 103(2):146-52 https://academic.oup.com/aesa/article-lookup/doi/10.1603/ AN09138.

58. de Guzman LI, Rinderer TE, Frake AM, Kirrane MJ. Brood removal influences fall of Varroa destructor in honey bee colonies. J Apic Res. 2016:54(3):216-25 http://www.tandfonline.com/doi/full/10.1080/00218839.2015.1117294.

59. Land BB, Seeley TD. The grooming invitation dance of the honey bee. Ethology. 2004;110(1):1-10.

60. Christine Peng YS, Fang Y, Xu S, Ge L, Nasr ME. Response of foster Asian honeybee (Apis cerana Fabr.) colonies to the brood of European honeybee (Apis mellifera L.) infested with parasitic mite, Varroa jacobsoni oudemans. J Invertebr Pathol. 1987:49(3):259-64.

61. Büchler R, Drescher W, Tornier I. Grooming behaviour ofApis cerana, Apis mellifera and Apis dorsata and its effect on the parasitic mites Varroa jacobsoni and Tropilaelaps clareae. Exp Appl Acarol. 1992;16(4):313-9.

62. Boecking O, Ritter W. Grooming and removal behavior of Apis mellifera intermissa in Tunesia against Varroa jacobsoni. J Apic Res. 1993;32:127-34.

63. Invernizzi C, Zefferino I, Santos E, Sánchez L, Mendoza Y. Multilevel assessment of grooming behavior against Varroa destructor in Italian and Africanized honey bees. J Apic Res. 2015:54(4):321-7 https://www. tandfonline.com/doi/full/10.1080/00218839.2016.1159055.

64. Aumeier P. Bioassay for grooming effectiveness towards Varroa destructor. Apidology. 2001;32:81-90.

65. Arechavaleta-Velasco ME, Guzman-Novoa E. Relative effect of four characteristics that restrain the population growth of the mite Varroa destructor in honey bee (Apis mellifera) colonies. Apidologie. 2001;32:157-74

66. Ruttner $\mathrm{H}$, Hanel F. Active defense against Varroa mites in a Carniolan strain of honeybee (Apis mellifera carnica Pollmann). Apidologie. 1992; 23:173-87.

67. Moosbeckhofer R. Beobachtungen zum Auftreten beschädigter Varroamilben im natürlichen Totenfall bei Völkern von Apis mellifera carnica (observations on the appearance of damaged Varroa mites in natural deadfall of Apis mellifera carnica colonies). Apidologie. 1992;23:523-31.

68. Mondragon L, Spivak M, Vandame R. A multifactorial study of the resistance of honeybees Apis mellifera to the mite Varroa destructor over one year in Mexico1. Apidologie. 2005;36:345-58 Springer Verlag.
69. Rosenkranz P, Fries I, Boecking O, Stürmer M. Damaged Varroa mites in the debris of honey bee (Apis mellifera $\mathrm{L}$ ) colonies with and without hatching brood. Apidologie. 1997;28(6):427-37.

70. Moretto G, Gonçalves LS, De Jong D, Bichuette MZ. The effects of climate and bee race on Varroa jacobsoni Oud infestations in Brazil. Apidologie. 1991;22:197-203 http://www.apidologie.org/10.1051/apido:19910303.

71. Ruttner H. Auf dem Wege zu einer Varroa-toleranten Carnica. Allg Dtsch Imkerztg. 1991;25:10-25.

72. Markthaler G. A safe method of detecting varroa resistnt colonies. Am Bee J. 2004:144:755-6.

73. Bąk B, Wilde J. Grooming behavior by worker bees of various subspecies of honey bees to remove Varroa destructor mites. J Apic Res. 2015;54(3):207-15 https://doi.org/10.1080/00218839.2016.1147791.

74. Hoffman S. Registration of damaged Varroa mites in small colonies for the assessment of grooming behavior. Apidologie. 1995:322-4.

75. Lobb N, Martin SJ. Mortality of Varroa jacobsoni Oudemans during or soon after emergence of worker and drone honeybees, Apis mellifera $\mathrm{L}$. Apidologie. 1997;28:367-74.

76. Martin S. A population model for the ectoparasitic mite Varroa jacobsoni in honey bee (Apis mellifera) colonies. Ecol Model. 1998;109(3):267-81.

77. Martin SJ, Kemp D. Average number of reproductive cycles performed by Varroa jacobsoni in honey bee ( Apis mellifera ). J Apic Res. 1997;36(3/4): 113-23.

78. Andino GK, Hunt GJ. A scientific note on a new assay to measure honeybee mite-grooming behavior. Apidologie. 2011;42(4):481-4.

79. Moretto G, Gonçalves LS, De Jong D. Heritability of Africanized and European honey bee defensive behavior against the mite Varroa jacobsoni. Rev Bras Genet. 1993;16(1):71-7.

80. Currie RW, Tahmasbi GH. The ability of high- and low-grooming lines of honey bees to remove the parasitic mite Varroa destructor is affected by environmental conditions. Can J Zool. 2008;86(9):1059-67 http://www. nrcresearchpress.com/doi/10.1139/Z08-083.

81. Kruitwagen A, van Langevelde F, van Dooremalen C, Blacquière T. Naturally selected honey bee (Apis mellifera) colonies resistant to Varroa destructor do not groom more intensively. J Apic Res. 2017;56(4):354-65 https://www. tandfonline.com/doi/full/10.1080/00218839.2017.1329797.

82. De Jong D. Africanized honeybees in Brazil, forty years of adaptation and success. Bee World. 1996:77:67-70.

83. Büchler R. Design and success of a German breeding program for Varroa tolerance. Am Bee J. 2000;140:662-5.

84. Büchler R, Berg S, Le Conte Y. Breeding for resistance to Varroa destructor in Europe. Apidologie. 2010;41(3):393-408.

85. Stanimirovič Z, Stevanović J, Aleksić N, Stojíc V. Heritability of grooming behaviour in grey honey bees (Apis mellifera carnica). Acta Vet Brno. 2010; 60(2-3):313-23.

86. Harbo JR, Harris JW. Selecting honey bees for resistance to Varroa jacobsoni. Apidologie. 1999;30(2-3):183-96 http://www.scopus.com/inward/record. url?eid=2-s2.0-0033008417\&partnerlD=40\&md5=94d8b9ee284ce 4 77a98e9a7e6920d0fc.

87. Martin S, Holland K, Murray M. Non-reproduction in the honeybee mite Varroa jacobsoni. Exp Appl Acarol. 1997;21:539-49.

88. Häußermann CK, Ziegelmann B, Rosenkranz P. Spermatozoa production in male Varroa destructor and its impact on reproduction in worker brood of Apis mellifera. Exp Appl Acarol. 2018;74(1):43-54 https://doi.org/10.1007/ s10493-018-0216-4.

89. Camazine S. Differential reproduction of the mite, Varroa jacobsoni (Mesostigmata: Varroidae), on Africanized and European honey bees (Hymenoptera: Apidae). Ann Entomol Soc Am. 1986;79(3):801-3.

90. Harbo JR, Harris JW. Resistance to Varroa destructor (Mesostigmata: Varroidae) when mite-resistant queen honey bees (Hymenoptera: Apidae) were free-mated with unselected drones. J Econ Entomol. 2001; 94(6):1319-23.

91. Ibrahim A, Spivak M. The relationship between hygienic behavior and suppression of mite reproduction as honey bee (Apis mellifera) mechanisms of resistance to Varroa destructor. Apidologie. 2006;37:31-40.

92. Behrens D, Huang Q, Geßner C, Rosenkranz P, Frey E, Locke B, et al. Three QTL in the honey bee Apis mellifera $L$. suppress reproduction of the parasitic mite Varroa destructor. Ecol Evol. 2011;1(4):451-8.

93. Conlon BH, Aurori A, Giurgiu Al, Kefuss J, Dezmirean DS, Moritz RFA, et al. A gene for resistance to the Varroa mite (Acari) in honey bee (Apis mellifera) pupae. Mol Ecol. 2019;28(October 2018):2958-66. 
94. Broeckx BJG, De Smet L, Blacquière T, Maebe K, Khalenkow M, Van Poucke $\mathrm{M}$, et al. Honey bee predisposition of resistance to ubiquitous mite infestations. Sci Rep. 2019;9(1):7794 http://www.nature.com/articles/s41598019-44254-8.

95. Conlon BH, Frey E, Rosenkranz P, Locke B, Moritz RFA, Routtu J. The role of epistatic interactions underpinning resistance to parasitic Varroa mites in haploid honey bee (Apis mellifera) drones. J Evol Biol. 2018;31(6):801-9.

96. Locke B. Inheritance of reduced Varroa mite reproductive success in reciprocal crosses of mite-resistant and mite-susceptible honey bees (Apis mellifera). Apidologie. 2016;47(4):583-8 https://doi.org/10.1007/s13592-0150403-9.

97. Locke B. Natural Varroa mite-surviving Apis mellifera honeybee populations Apidologie. 2016;47(3):467-82 https://doi.org/10.1007/s13592-015-0412-8.

98. Nganso BT, Fombong AT, Yusuf AA, Pirk CWW, Stuhl C, Torto B. Low fertility, fecundity and numbers of mated female offspring explain the lower reproductive success of the parasitic mite Varroa destructor in African honeybees. Parasitology. 2018:1-7.

99. Oddie MAY, Dahle B, Neumann P. Norwegian honey bees surviving Varroa destructor mite infestations by means of natural selection. PeerJ. 2017;5: e3956 https://peerj.com/articles/3956.

100. Oldroyd BP. Coevolution while you wait: Varroa jacobsoni, a new parasite of western honeybees. Trends Ecol Evol. 1999;14(8):312-5.

101. Frey $E$, Odemer R, Blum T, Rosenkranz P. Activation and interruption of the reproduction of Varroa destructor is triggered by host signals (Apis mellifera). J Invertebr Pathol. 2013;113(1):56-62 https://doi.org/10.1016/j.jip.2013.01.007.

102. Hänel $\mathrm{H}$. Effect of $\mathrm{JH}_{\|}$on the reproduction of Varroa jacobsoni. Apidology. 1983:14:137-42

103. Hänel H, Koeniger N. Possible regulation of the reproduction of the honey bee mite Varroa jacobsoni (Mesostigmata: Acari) by a host's hormone: juvenile hormone III. J Insect Physiol. 1986;32:137-42.

104. Rosenkranz P, Rachinsky A, Strambi A, Strambi C, Röpstorf P. Juvenile hormone titer in capped worker brood of Apis mellifera and reproduction in the bee mite Varroa jacobsoni. Gen Comp Endocrinol. 1990;78(2):189-93.

105. Rosenkranz P, Tewarson N, Rachinsky A, Strambi A, Strambi C, Engels W. Juvenile hormone titer and reproduction of Varroa jacobsoni in capped brood stages of Apis cerana indica in comparison to Apis mellifera ligustica. Apidologie. 1993;24:375-82.

106. Cabrera AR, Shirk PD, Evans JD, Hung K, Sims J, Alborn H, et al. Three Halloween genes from the Varroa mite, Varroa destructor (Anderson \& Trueman) and their expression during reproduction. Insect Mol Biol. 2015; 24(3):277-92.

107. Lattorff HMG, Buchholz J, Fries I, Moritz RFA. A selective sweep in a Varroa destructor resistant honeybee (Apis mellifera) population. Infect Genet Evol. 2015;31:169-76 https://doi.org/10.1016/j.meegid.2015.01.025.

108. Kurze C, Routtu J, Moritz RFA. Parasite resistance and tolerance in honeybees at the individual and social level. Zoology. 2016;119(4):290-7 https://doi.org/10.1016/j.zool.2016.03.007.

109. Villa JD, Danka RG, Harris JW. Selecting honeybees for worker brood that reduces the reproduction of Varroa destructor. Apidologie. 2016;47(6):771-8.

110. Wagoner KM, Spivak M, Rueppell O. Brood Affects Hygienic Behavior in the Honey Bee (Hymenoptera: Apidae). J Econ Entomol. 2018;111(6):2520-30 http://www.ncbi.nlm.nih.gov/pubmed/30212863.

111. Baudoux U. The influence of cell size. Bee World. 1933;1.

112. Erickson EH, Lusby DA, Hoffman GD, Lusby EW. On the size of cells: speculations on foundation as a management colony tool. Bee Cult. 1990; 118:98-101 and 173-4.

113. Heaf D. Do small cells help bees cope with Varroa? A review. 2011;104:39-45.

114. Martin SJ, Kryger P. Reproduction of Varroa destructor in south African honeybees: does cell space influence Varroa male survivorship. Apidologie. 2002;33(1):51-61 Springer Verlag.

115. Seeley TD, Griffin SR. Small-cell comb does not control Varroa mites in colonies of honeybees of European origin. Apidologie. 2011;42(4):526-32.

116. Message D, Gonçalves LS. Effect of the size of worker brood cells of Africanized honey bees on infestation and reproduction of the ectoparasitic mite Varroa jacobsoni Oud. Apidologie. 1995;26(5):381-6.

117. Coffey MF, Breen J, Brown MJF, McMullan JB. Brood-cell size has no influence on the population dynamics of Varroa destructor mites in the native western honey bee, Apis mellifera mellifera. Apidologie. 2010;41(5): 522-30.

118. Ellis AM, Hayes GW, Ellis JD. The efficacy of small cell foundation as a varroa mite (Varroa destructor) control. Exp Appl Acarol. 2009;47(4):311-6.
119. Berry JA, Owens WB, Delaplane KS. Small-cell comb foundation does not impede Varroa mite population growth in honey bee colonies. Apidologie. 2010;41(1):40-4

120. Maggi M, Damiani N, Ruffinengo S, de Jong D, Principal J, Eguaras M. Brood cell size of Apis mellifera modifies the reproductive behavior of Varroa destructor. Exp Appl Acarol. 2010;50(3):269-79.

121. Piccirillo GA, De Jong D. The influence of brood comb cell size on the reproductive behavior of the ectoparasitic mite Varroa destructor in Africanized honey bee colonies. Genet Mol Res. 2003;2(1):36-42.

122. Singer HJ, van Praagh JP, Paulus HF. Interactions between honeybees and Varroa mites influenced by cell sizes and hygienic behaviour. Entomol Gen. 2019;38(3):255-73.

123. Olszewski K, Borsuk G, Paleolog J, Strachecka A, Bajda M. Hygienic behaviour of colonies kept on small-cell combs. Med Weter. 2014;70(12):2013-5.

124. Remnant EJ, Mather N, Gillard TL, Yagound B, Beekman M. Direct transmission by injection affects competition among RNA viruses in honeybees. Proc R Soc B Biol Sci. 2019;286:20182452 https://doi.org/10. 1098/rspb.2018.2452

125. Allsopp MH. Analysis of Varroa destructor infestation of Southern African honeybee populations. MSC Thesis Nat Agric Sci Univ Pretoria. 2006;(June): 285.

126. Brettell LE, Martin SJ. Oldest Varroa tolerant honey bee population provides insight into the origins of the global decline of honey bees. Sci Rep. 2017;7: 45953 https://doi.org/10.1038/srep45953.

127. Mordecai GJ, Brettell LE, Martin SJ, Dixon D, Jones IM, Schroeder DC. Superinfection exclusion and the long-term survival of honey bees in Varroa-infested colonies. ISME J. 2016;10(5):1182-91. https://doi.org/10.1038/ ismej.2015.186.

128. Seeley TD. Honey bees of the Arnot Forest: a population of feral colonies persisting with Varroa destructor in the northeastern United States. Apidologie. 2007;38(1):19-29 http://link.springer.com/10.1051/apido:2006055.

129. Fries I, Imdorf A, Rosenkranz P. Survival of mite infested (Varroa destructor) honey bee (Apis mellifera) colonies in a Nordic climate. Apidologie. 2006;37: 564-70.

130. Locke B, Forsgren E, De Miranda JR. Increased tolerance and resistance to virus infections: A possible factor in the survival of Varroa destructor-resistant honey bees (Apis mellifera). PLoS One. 2014;9:6.

131. Locke B, Semberg E, Forsgren E, De Miranda JR. Persistence of subclinical deformed wing virus infections in honeybees following Varroa mite removal and a bee population turnover. PLoS One. 2017;12(7):1-10.

132. Thaduri S, Locke B, Granberg F, De Miranda JR. Temporal changes in the viromes of swedish Varroa-resistant and varroa-susceptible honeybee populations. PLoS One. 2018;13(12):1-17.

133. Thaduri S, Stephan JG, de Miranda JR, Locke B. Disentangling host-parasitepathogen interactions in a Varroa-resistant honeybee population reveals virus tolerance as an independent, naturally adapted survival mechanism. Sci Rep. 2019:9(1):1-10.

134. Strauss U, Human H, Gauthier L, Crewe RM, Dietemann V, Pirk CWW. Seasonal prevalence of pathogens and parasites in the savannah honeybee (Apis mellifera scutellata). J Invertebr Pathol. 2013;114(1):45-52.

135. Schöning C, Gisder S, Geiselhardt S, Kretschmann I, Bienefeld K, Hilker M, et al. Evidence for damage-dependent hygienic behaviour towards Varroa destructor-parasitised brood in the western honey bee, Apis mellifera. J Exp Biol. 2012;215(2):264-71.

136. Loftus JC, Smith ML, Seeley TD. How honey bee colonies survive in the wild: testing the importance of small nests and frequent swarming. PLoS One. 2016;11(3):1-11.

137. Seeley TD. Life-history traits of wild honey bee colonies living in forests around Ithaca, NY, USA. Apidologie. 2017:48:743-54 http://link.springer. com/10.1007/s13592-017-0519-1.

138. Seeley TD, Smith ML. Crowding honeybee colonies in apiaries can increase their vulnerability to the deadly ectoparasite Varroa destructor. Apidologie. 2015;46(6):716-27

139. Peck DT, Seeley TD. Mite bombs or robber lures? The roles of drifting and robbing in Varroa destructor transmission from collapsing honey bee colonies to their neighbors. PLoS One. 2019;14(6):1-14.

140. Wilfert L, Gadau J, Schmid-Hempel P. Variation in genomic recombination rates among animal taxa and the case of social insects. Heredity (Edinb). 2007;98(4):189-97.

141. Matilla HR, Seeley TD. Genetic diversity in honey bee colonies enhances productivity and fitness. Science. 2007;317:362-5. 
142. Mattila HR, Seeley TD. Extreme polyandry improves a honey bee colony's ability to track dynamic foraging opportunities via greater activity of inspecting bees. Apidologie. 2014;45(3):347-63.

143. Mattila HR, Reeve HK, Smith ML. Promiscuous honey bee queens increase colony productivity by suppressing worker selfishness. Curr Biol. 2012;22(21): 2027-31 https://doi.org/10.1016/j.cub.2012.08.021.

144. Gries M, Koeniger N. Straight forward to the queen: pursuing honeybee drones (Apis mellifera L.) adjust their body axis to the direction of the queen. J Comp Physiol - A Sensory, Neural, Behav Physiol. 1996;179(4): 539-44.

145. Estoup A, Solignac M, Cornuet JM. Precise assessment of the number of patrilines and of genetic relatedness in honeybee colonies. Proc R Soc B Biol Sci. 1994:258(1351):1-7.

146. Palmer KA, Oldroyd BP. Evolution of multiple mating in the genus Apis. Apidologie. 2000;31(2):235-48.

147. Jensen AB, Palmer KA, Chaline N, Raine NE, Tofilski A, Martin SJ, et al. Quantifying honey bee mating range and isolation in semi-isolated valleys by DNA microsatellite paternity analysis. Conserv Genet. 2005;6(4):527-37.

148. Baudry E, Solignac M, Garnery L, Gries M, Cornuet J, Koeniger N. Relatedness among honeybees (Apis mellifera) of a drone congregation. Proc R Soc B Biol Sci. 1998;265(1409):2009-14 http://rspb.royalsocietypublishing.org/cgi/ doi/10.1098/rspb.1998.0533.

149. Jaffé $R$, Dietemann $V$, Crewe RM, Moritz RFA. Temporal variation in the genetic structure of a drone congregation area: an insight into the population dynamics of wild African honeybees (Apis mellifera scutellata). Mol Ecol. 2009;18(7):1511-22.

150. Hepburn HR, Crewe RM. Portrait of the cape honeybee, Apis mellifera capensis. Apidologie. 1991;22:567-80.

151. Benjeddou M, Leat N, Allsopp M, Davison S. Detection of acute bee paralysis virus and black queen cell virus from honeybees by reverse transcriptase PCR. Appl Environ Microbiol. 2001;67(5):2384-7.

152. Muli E, Patch $H$, Frazier M, Frazier J, Torto B, Baumgarten T, et al. Evaluation of the distribution and impacts of parasites, pathogens, and pesticides on honey bee (Apis mellifera) populations in east Africa. PLoS One. 2014;9:4.

153. Fazier M, Muli E, Conklin T, Schmehl D, Torto B, Frazier J, et al. A scientific note on Varroa destructor found in East Africa; threat or opportunity? Apidologie. 2010;41(4):463-5.

154. Nganso BT, Fombong AT, Yusuf AA, Pirk CWW, Stuhl C, Torto B. Hygienic and grooming behaviors in African and European honeybees-new damage categories in Varroa destructor. PLoS One. 2017;12(6):e0179329 https://www. ncbi.nlm.nih.gov/pubmed/28622341.

155. Raina SD, Fries I. American foulbrood and African honey bees (Hymenoptera : Apidae ). J Econ Entomol. 2004;96(January):1641-6.

156. Spivak M, Reuter GS. Performance of hygienic honey bee colonies in a commercial apiary. Apidologie. 1998;29(3):291-302.

157. Strauss U, Dietemann V, Human H, Crewe RM, Pirk CWW. Resistance rather than tolerance explains survival of savannah honeybees (Apis mellifera scutellata) to infestation by the parasitic mite Varroa destructor. Parasitology. 2016:143(3):374-87.

158. Calderón RA, van Veen JW, Sommeijer MJ, Sanchez LA. Reproductive biology of Varroa destructor in Africanized honey bees (Apis mellifera). Exp Appl Acarol. 2010;50(4):281-97.

159. Moritz RF a, Hänel H. Restricted development of the parasitic mite Varroa jacobsoni Oud. in the Cape honeybee Apis mellifera capensis Esch.. Zeitschrift für angewante. Entomol. 1984;7:91-5.

160. Rosenkranz P. Honey bee (Apis mellifera L.) tolerance to Varroa jacobsoni Oud. In South America. Apidologie. 1999;30(2-3):159-72.

161. Medina LM, Martin SJ. A comparative study of Varroa jacobsoni reproduction in worker cells of honey bees (Apis mellifera) in England and Africanized bees in Yucatan, Mexico. Exp Appl Acarol. 1999;23(8):659-67.

162. Martin SJ, Medina LM. Africanized honeybees have unique tolerance to Varroa mites. Trends Parasitol. 2004;20(3):112-4.

163. Pinto FA, Puker A, Message D, Barreto LMRC. Infestation rate of the mite Varroa destructor in commercial apiaries of the Vale do Paraíba and Serra da Mantiqueira, southeastern Brazil. Arq Bras Med Vet e Zootec. 2015;67(2):631-5.

164. Chagas DB, Monteiro FL, de Hübner SO, de Lima M, Fischer G. Viruses that affect Apis mellifera and their occurrence in Brazil. Ciência Rural. 2019;49:9 https://doi.org/10.1590/0103-8478cr20181042.

165. Ding G, Fondevila N, Palacio MA, Merke J, Martinez A, Camacho B, et al. Prevalence of honeybee viruses in different regions of China and Argentina. OIE Rev Sci Tech. 2016;35(3):825-33.
166. Maggi M, Antúnez K, Invernizzi C, Aldea P, Vargas $M$, Negri $P$, et al. Honeybee health in South America. Apidologie. 2016;47(6):835-54.

167. Teixeira EW, Chen Y, Message D, Pettis J, Evans JD. Virus infections in Brazilian honey bees. J Invertebr Pathol. 2008;99(1):117-9.

168. Reyes-Quintana M, Espinosa-Montaño LG, Prieto-Merlos D, Koleoglu G, Petukhova T, Correa-Benítez A, et al. Impact of Varroa destructor and deformed wing virus on emergence, cellular immunity, wing integrity and survivorship of Africanized honey bees in Mexico. J Invertebr Pathol. 2019; 164:43-8 https://doi.org/10.1016/j.jip.2019.04.009.

169. Hamiduzzaman MM, Guzman-Novoa E, Goodwin PH, Reyes-Quintana M, Koleoglu G, Correa-Benítez A, et al. Differential responses of Africanized and European honey bees (Apis mellifera) to viral replication following mechanical transmission or Varroa destructor parasitism. J Invertebr Pathol. 2015;126:12-20 https://doi.org/10.1016/j.jip.2014.12.004

170. Vandame R, Morand S, Colin ME, Belzunces LP. Parasitism in the social bee Apis mellifera: quantifying costs and benefits ofbehavioral resistance to Varroa destructor mites. Apidologie. 2002;33:433-45 Springer Verlag.

171. Corrêa-Marques MH, De Jong D. Uncapping of worker bee brood, a component of the hygienic behavior of Africanized honey bees against the mite Varroa jacobsoni Oudemans. Apidologie. 1998;29:283-9.

172. Le Conte Y, Alaux C, Martin JF, Harbo JR, Harris JW, Dantec C, et al. Social immunity in honeybees (Apis mellifera): Transcriptome analysis of Varroahygienic behaviour. Insect Mol Biol. 2011;20(3):399-408.

173. Corrêa-Marques MH, Medina LM, Martin SJ, De Jong D. Comparing data on the reproduction of Varroa destructor. Genet Mol Res. 2003;2(1):1-6.

174. Vandame R, Colin M-E, Morand S, Otero-Colina G. Levels of compatibility in a new host-parasite association: Apis melliferaNarroa jacobsoni. Can J Zool. 2000;78(11):2037-44.

175. Visscher PK, Seeley TD. Foraging strategy of honeybee colonies in a temperate deciduous Forest. Ecology. 1982;63(6):1790-801.

176. Mikheyev AS, Tin MMY, Arora J, Seeley TD. Museum samples reveal rapid evolution by wild honey bees exposed to a novel parasite. Nat Commun. 2015;6:1-8 https://doi.org/10.1038/ncomms8991.

177. Seeley TD. The lives of bees the untold story of the honey bee in the wild. Princeton: Princeton University Press; 2019.

178. Pesenko Y, Lelej A, Radchenko V, Filatkin G. The Chinese wax bee Apis cerana cerana F. (Hymenoptera, Apidae) in the soviet Far East. Entomol Rev. 1990;69(3):21-46.

179. Crane E. The Varroa mite. Bee World. 1978;59(4):164-7.

180. Danka RG, Rinderer TE, Kuznetsov VN, Delatte GT. A USDA-ARS project to evaluate resistance to Varroa jacobsoni by honeybees of far-eastern Russia. Am Bee J. 1995;135:746-8.

181. Rinderer TE, De Guzman LI, Harris JW, Kuznetsov VN, Delatte GT, Stelzer JA, et al. The release of ARS Russian honeybees. Am Bee J. 2000;140(4): $305-7$.

182. Rinderer T, Kuznetsov VN, Danka RG, Delatte GT. An importation of potentially Varroa resistant honey bees from far eastern Russia. Pdf Am Bee J. 1997;137(11):787-9.

183. Rinderer TE, Delatte GT, De Guzman LI, Williams JL, Stelzer JA, Kuznetsov VN Evaluations of the Varroa-resistance of honey bees imported from fareastern Russia. Am Bee J. 1999;139(4):287-90.

184. Rinderer E, Guzman LDE, Danka R. A new phase begins for the USDA-ARS Russian honeybee breeding program. Am Bee J. 2005;145(6):579-82.

185. Guzman LIDE, Rinderer TE, Frake AM. Growth of Varroa destructor (Acari: Varroidae) populations in Russian honey bee (Hymenoptera: Apidae) colonies. Ecol Popul Biol. 2007;100(2):187-95.

186. de Guzman LI, Rinderer TE, Frake AM. Comparative reproduction of Varroa destructor in different types of Russian and Italian honey bee combs. Exp Appl Acarol. 2008;44(3):227-38.

187. Tubbs H, Harper C, Bigalk M, Bernhard SJ, Delatte GT, Sylvester HA, et al. Commercial management of ARS Russian honeybees. Am Bee J. 2003;144: 819-20

188. Arathi HS, Spivak M. Influence of colony genotypic composition on the performance of hygienic behaviour in the honeybee, Apis mellifera L. Anim Behav. 2001;62(1):57-66.

189. Kulincevic JM, Rinderer TE, Mladjan VJ, Buco SM. Five years of bi-directional genetic selection for honey bees resistant and susceptible to Varroa jacobsoni. Apidologie. 1992;23(5):443-52.

190. Le Conte Y, De VG, Didier C, François J, Anderson V. Honey bee colonies that have survived Varroa destructor. Apidologie. 2007;38:566-72. 
191. Kefuss J, Vanpoucke J, De Lahitte JD, Ritter W. Varroa tolerance in France of intermissa bees from Tunisia and their naturally mated descendants: 19932004. Am Bee J. 2004;144(7):563-8.

192. Kefuss J, Vanpoucke J, Bolt M, Kefuss C. Selection for resistance to Varroa destructor under commercial beekeeping conditions. J A Apic Res. 2015;54(5): 563-76 https://www.tandfonline.com/doi/full/10.1080/00218839.2016.1160709.

193. Panziera D, van Langevelde F, Blacquière T. Varroa sensitive hygiene contributes to naturally selected Varroa resistance in honey bees. J Apic Res. 2017;56(5):635-42 https://www.tandfonline.com/doi/full/10.1080/00218839.2 017.1351860.

194. Fries I, Bommarco R. Possible host-parasite adaptations in honey bees infested by Varroa destructor mites. Apidologie. 2007;38(6):525-33 http://ink. springer.com/10.1051/apido:2007039.

195. Locke B, Fries I. Characteristics of honey bee colonies (Apis mellifera) in Sweden surviving Varroa destructor infestation. Apidologie. 2011:42(4):533-42.

196. Le Conte Y, Mondet F. Natural selection of honeybees against Varroa destructor. In: Vreeland RH, Sammatoro D, editors. Beekeeping- From Science to Practice. In: Springer; 2017. p. 189-94.

197. Büchler R, Costa C, Hatjina F, Andonov S, Meixner MD, Le Conte Y, et al. The influence of genetic origin and its interaction with environmental effects on the survival of Apis mellifera L. colonies in Europe. J Apic Res. 2014;53(2): 205-14 https://www.tandfonline.com/doi/full/10.3896/BRA.1.53.2.03.

198. Locke B, Le Conte Y, Crauser D, Fries I. Host adaptations reduce the reproductive success of Varroa destructor in two distinct European honey bee populations. Ecol Evol. 2012;2(6):1144-50.

199. Navajas M, Migeon A, Alaux C, Martin-Magniette ML, Robinson GE, Evans JD, et al. Differential gene expression of the honey bee Apis mellifera associated with Varroa destructor infection. BMC Genomics. 2008;9:1-11.

200. Oddie MAY, Dahle B, Neumann P. Reduced postcapping period in honey bees surviving Varroa destructor by means of natural selection. Insects. 2018; 9(4) https://doi.org/10.3390/insects9040149.

201. Adjlane N, Haddad N. The first data on hygienic behavior of Apis mellifera intermissa in Algeria. J Biol Earth Sci. 2013;4(1):1-5.

\section{Publisher's Note}

Springer Nature remains neutral with regard to jurisdictional claims in published maps and institutional affiliations.

Ready to submit your research? Choose BMC and benefit from:

- fast, convenient online submission

- thorough peer review by experienced researchers in your field

- rapid publication on acceptance

- support for research data, including large and complex data types

- gold Open Access which fosters wider collaboration and increased citations

- maximum visibility for your research: over $100 \mathrm{M}$ website views per year

At $\mathrm{BMC}$, research is always in progress.

Learn more biomedcentral.com/submissions 